DOE/NV/10845-35

\title{
THE APPLICATION OF BOREHOLE LOGGING TO CHARACTERIZE THE HYDROGEOLOGY OF THE FAULTLESS SITE, CENTRAL NEVADA TEST AREA
}

\author{
by \\ J.B. Chapman \\ T.M. Mihevc \\ B.F. Lyles
}

August 1994

Publication \#45119 
This report was prepared as an account of work sponsored by the United States Government. Neither the United States nor the United States Department of Energy, nor any of their employees, makes any warranty, express or implied, or assumes any legal liability or responsibility for the accuracy, completeness or usefulness of any information, apparatus, product or process disclosed, or represents that its use would not infringe privately owned rights. Reference herein to any specific commercial product, process, or service by trade name, mark, manufacturer, or otherwise, does not necessarily constitute or imply its endorsement, recommendation, or favoring by the United States Government or any agency thereof. The views and opinions of authors expressed herein do not necessarily state or reflect those of the United States Government or any agency thereof.

This report has been reproduced directly from the best available copy.

Available to DOE and DOE contractors from the Office of Scientific and Technical Information, P.O. Box 62, Oak Ridge, TN 37831; prices available from (615) 576-8401.

Available to the public from the National Technical Information Service, U.S. Department of Commerce, 5285 Port Royal Rd., Springfield, VA 22161. 


\section{DISCLAIMER}

Portions of this document may be illegible in electronic image products. Images are produced from the best available original document. 


\title{
THE APPLICATION OF BOREHOLE LOGGING TO CHARACTERIZE THE HYDROGEOLOGY OF THE FAULTLESS SITE, CENTRAL NEVADA TEST AREA
}

\author{
by \\ J.B. Chapman \\ T.M. Mihevc \\ B.F. Lyles \\ Water Resources Center \\ Desert Research Institute \\ University and Community College System of Nevada
}

Publication No. 45119

prepared for

Nevada Operations Office

U.S. Department of Energy

Las Vegas, Nevada

August 1994

The work upon which this report is based was supported by the U.S. Department of Energy under Contract \#DE-AC08-90NV10845.

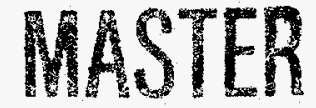

DISTFRUTHON OF THE DOCUAMENT IS LALLATIED

$$
\checkmark K
$$




\begin{abstract}
The Central Nevada Test Area was the site of the "Faultless" underground nuclear test that could be a source of radionuclide contamination to aquifers in Hot Creek Valley, Nevada. Field studies in 1992 and 1993 have used hydrologic logging and water sampling to determine the adequacy of the current groundwater monitoring network and the status of water-level recovery to pre-shot levels in the nuclear chimney. The field studies have determined that there is a possibility for contaminant migration away from the Faultless event though the pre-event water level has not been attained, while new data raise questions about the ability of the current monitoring network to detect migration. Hydrologic logs from the postshot hole (drilled into the chimney created by the nuclear detonation) reveal inflow around $485 \mathrm{~m}$ below land surface. This inflow drives strong vertical flow both up and down the well to outflow zones around 350 and $600 \mathrm{~m}$. The physical and chemical characteristics of the inflow water indicate that its source is much deeper in the chimney, perhaps driven upward in a convection cell generated by heat near the nuclear cavity. Hydrologic relationships between the chimney and surrounding alluvium are unknown, but if the low-pressure drain encountered at $350 \mathrm{~m}$ extends beyond the chimney, it is possible that migration has been occurring for the last decade, when water levels rose above that horizon. Logging and sampling at monitoring wells $\mathrm{HTH}-1$ and $\mathrm{HTH}-2$ revealed that the completion of HTH-1 may be responsible for its elevated water level (as compared to pre-nuclear test levels) and may have also created a local mound in the water table in the alluvium that accounts for higher post-test water levels at HTH-2. This mound would serve to divert flow around the monitoring wells, so that only migration of contaminants through the underlying, higher pressure, volcanic units is currently monitored. A hydraulic high found in an abandoned hole located between the nuclear chimney and the monitoring wells further reduces the likelihood of HTH-1 or HTH-2 intercepting contaminant migration. Conditions in HTH-1 and the postshot hole have changed over the long term; changes at the postshot hole are due to the nuclear test, while HTH-1 may be responding either to the test or equilibrating to its multizone completion. Short-term physical and chemical differences may be part of these long-term trends or represent shorter-term fluctuations.
\end{abstract}




\section{CONTENTS}

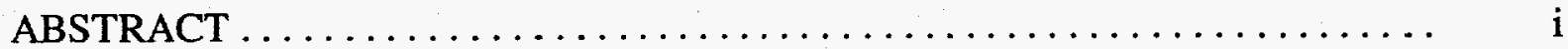

LIST OF FIGURES $\ldots \ldots \ldots \ldots \ldots \ldots \ldots \ldots \ldots \ldots \ldots \ldots \ldots \ldots \ldots \ldots \ldots \ldots \ldots$

LIST OF TABLES $\ldots \ldots \ldots \ldots \ldots \ldots \ldots \ldots \ldots \ldots \ldots \ldots \ldots \ldots \ldots \ldots \ldots \ldots \ldots \ldots$

INTRODUCTION $\ldots \ldots \ldots \ldots \ldots \ldots \ldots \ldots \ldots \ldots \ldots \ldots \ldots \ldots \ldots \ldots \ldots$

HYDROGEOLOGIC SETTING $\ldots \ldots \ldots \ldots \ldots \ldots \ldots \ldots \ldots \ldots \ldots \ldots$

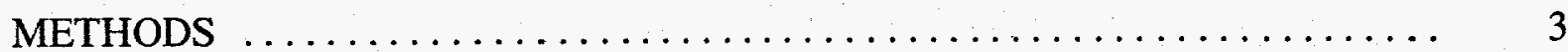

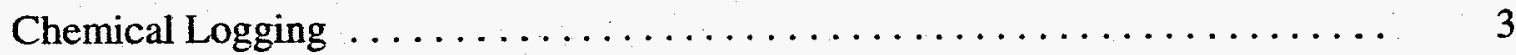

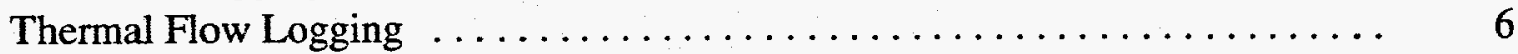

Sample Collection $\ldots \ldots \ldots \ldots \ldots \ldots \ldots \ldots \ldots \ldots \ldots \ldots \ldots \ldots \ldots \ldots$

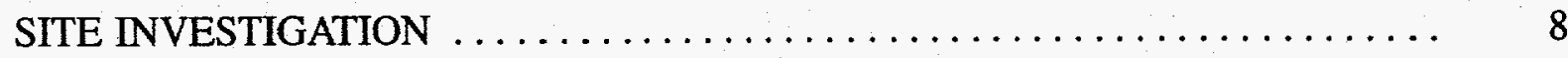

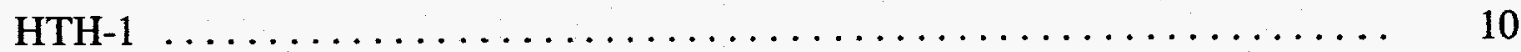

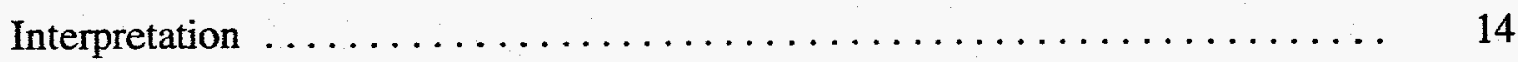

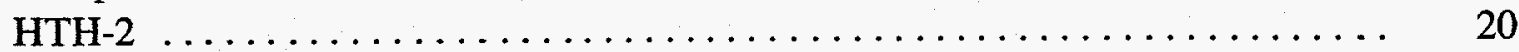

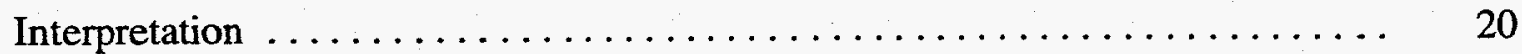

UC-1-P-1S . . . . . . . . . . . . .

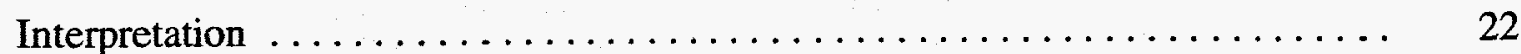

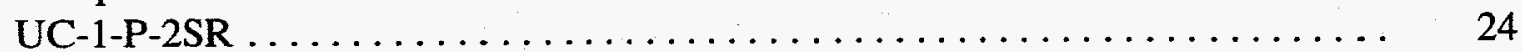

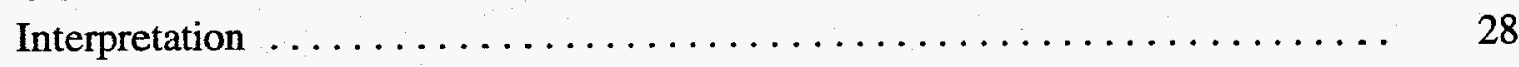

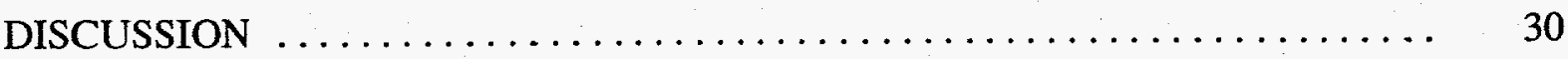

Conditions Outside the Collapse Block $\ldots \ldots \ldots \ldots \ldots \ldots \ldots \ldots \ldots \ldots \ldots \ldots \ldots$

Conditions Inside the Collapse Block $\ldots \ldots \ldots \ldots \ldots \ldots \ldots \ldots \ldots \ldots \ldots$

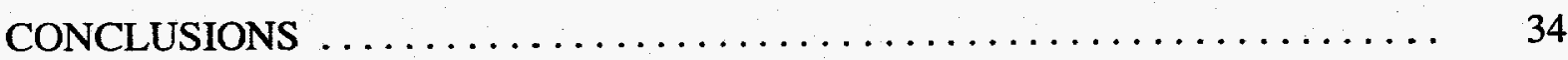

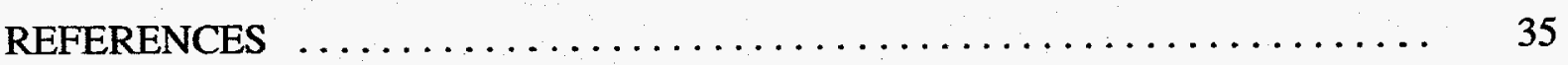




\section{LIST OF FIGURES}

1. Location of the three land areas withdrawn for the Central Nevada Test Area

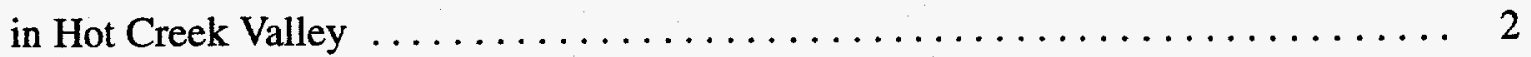

2. Location of wells near the Faultless site at the Central Nevada Test Area ........ 4

3. Schematic diagram of the Chem-tool $\ldots \ldots \ldots \ldots \ldots \ldots \ldots \ldots \ldots \ldots \ldots, 5$

4. Schematic diagram of the thermal flowmeter $\ldots \ldots \ldots \ldots \ldots \ldots \ldots \ldots, 7$

5. Typical heat-pulse responses from the thermal flowmeter $\ldots \ldots \ldots \ldots \ldots \ldots$

6. Temperature logs from boreholes at the Faultless site, with the proposed local

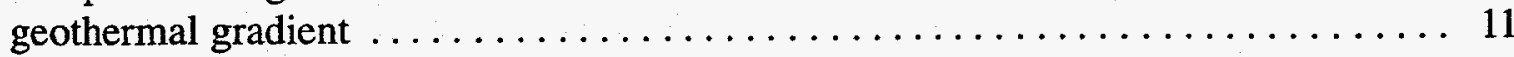

7. Borehole completion and hydrologic logs from HTH-1 $\ldots \ldots \ldots \ldots \ldots \ldots \ldots 12$

8. Trilinear diagram of water analyses from the Faultless site $\ldots \ldots \ldots \ldots \ldots \ldots$

9. Deuterium and ${ }^{18} \mathrm{O}$ composition of water samples at the Faultless site $\ldots \ldots \ldots \ldots 17$

10. Borehole completion and hydro-chemical logs from $\mathrm{HTH}-2 \ldots \ldots \ldots \ldots \ldots \ldots$

11. Borehole completion and hydro-chemical logs from UC-1-P-1S $\ldots \ldots \ldots \ldots \ldots 21$

12. Borehole completion and hydro-chemical $\log$ from UC-1-P-2SR $\ldots \ldots \ldots \ldots \ldots 23$

13. Water elevation history for boreholes at the Faultless site $\ldots \ldots \ldots \ldots \ldots \ldots 25$

14. Chemical and thermal flow $\log$ from UC-1-P-2SR $\ldots \ldots \ldots \ldots \ldots \ldots \ldots \ldots$

15. Comparison of May and November temperature logs from UC-1-P-2SR $\ldots \ldots \ldots 28$

16. Tritium concentration through time for water samples collected a) at $668 \mathrm{~m}$, and $b$ ) between 454 and $466 \mathrm{~m}$ in UC-1-P-2SR $\ldots \ldots \ldots \ldots \ldots \ldots \ldots \ldots \ldots \ldots$

17. Water elevation history for boreholes at the Faultless site $\ldots \ldots \ldots \ldots \ldots \ldots \ldots, 32$

\section{LIST OF TABLES}

1. Chemical and Isotopic Analyses of Groundwater Samples from the Faultless Site ... 15 


\section{INTRODUCTION}

In the process of addressing environmental regulations, hydrogeologists are often faced with sparse data for initial site evaluations. It is important for economic, environmental, and scientific reasons to maximize the information gained from existing wells prior to embarking on full remedial investigations. For example, there is a real danger of spreading contamination during field studies unless the site hydrogeology is understood. At sites with wells screened through several hundred feet of water-bearing material, hydrologic logging is an important tool for obtaining the most information possible.

Geophysical logging methods are most often applied in wells during or shortly after drilling to aid in identifying and correlating geologic units, and to provide information on the nature of interstitial fluids and fluid-bearing properties of the formations. Many of these same geophysical

logs, as well as some designed specifically for hydrologic uses, can be applied to groundwater studies (Keys and MacCary, 1971). The investigation described below uses five evaluation methods: temperature logs, fluid electrical conductivity (EC) logs, $\mathrm{pH}$ logs, thermal flowmeter surveys, and water chemistry samples.

The study site is known as the Central Nevada Test Area (CNTA) and was considered for testing high yield nuclear explosives that could not be detonated at the Nevada Test Site due to the proximity to Las Vegas. Only one test was conducted at the CNTA, the Project Faultless event on January 19, 1968. The detonation was $975 \mathrm{~m}$ below land surface and created an unusual collapse crater: a large, irregular subsidence block bounded by local faults, rather than the typical saucer-shaped depression. Groundwater monitoring at the site is conducted annually as part of the Department of Energy's Long-Term Hydrologic Monitoring Program. Unfortunately, many of the sampling points are too distant from the site to detect migration (Chapman and Hokett, 1991), but the wells HTH-1 and HTH-2 are located within $1,500 \mathrm{~m}$ of the event, are completed in the hydrologic units intercepted by the cavity, and are in the presumed downgradient direction. In addition, water levels in a postshot hole (drilled into the cavity) have been regularly recorded by the U.S. Geological Survey, and occasional samples collected. Logging and sampling results from the postshot and monitoring wells are used to evaluate the existing monitoring network and the potential for contaminant release.

\section{HYDROGEOLOGIC SETTING}

The CNTA is located in Hot Creek Valley, Nevada (Figure 1), within the Great Basin physiographic province. The valley is a long graben containing a sequence of Quaternary and Tertiary alluvial fill (up to $1200 \mathrm{~m}$ ) underlain by a thick section of Tertiary volcanic rocks. The bounding ranges on either side of the valley contain Paleozoic carbonates overlain by Tertiary age volcanics (Thordarson, 1987). Boreholes close to the site generally penetrate approximately $610 \mathrm{~m}$ of alluvium underlain by tuffaceous sediments and volcanic rocks.

Groundwater in the alluvium is believed to follow the general direction of surface flow (Rush and Everett, 1966; Fiero et al., 1974) with recharge in the higher mountain range to the west (Hot Creek Range) and discharge by evaporation in low portions of the valley and by surface and 


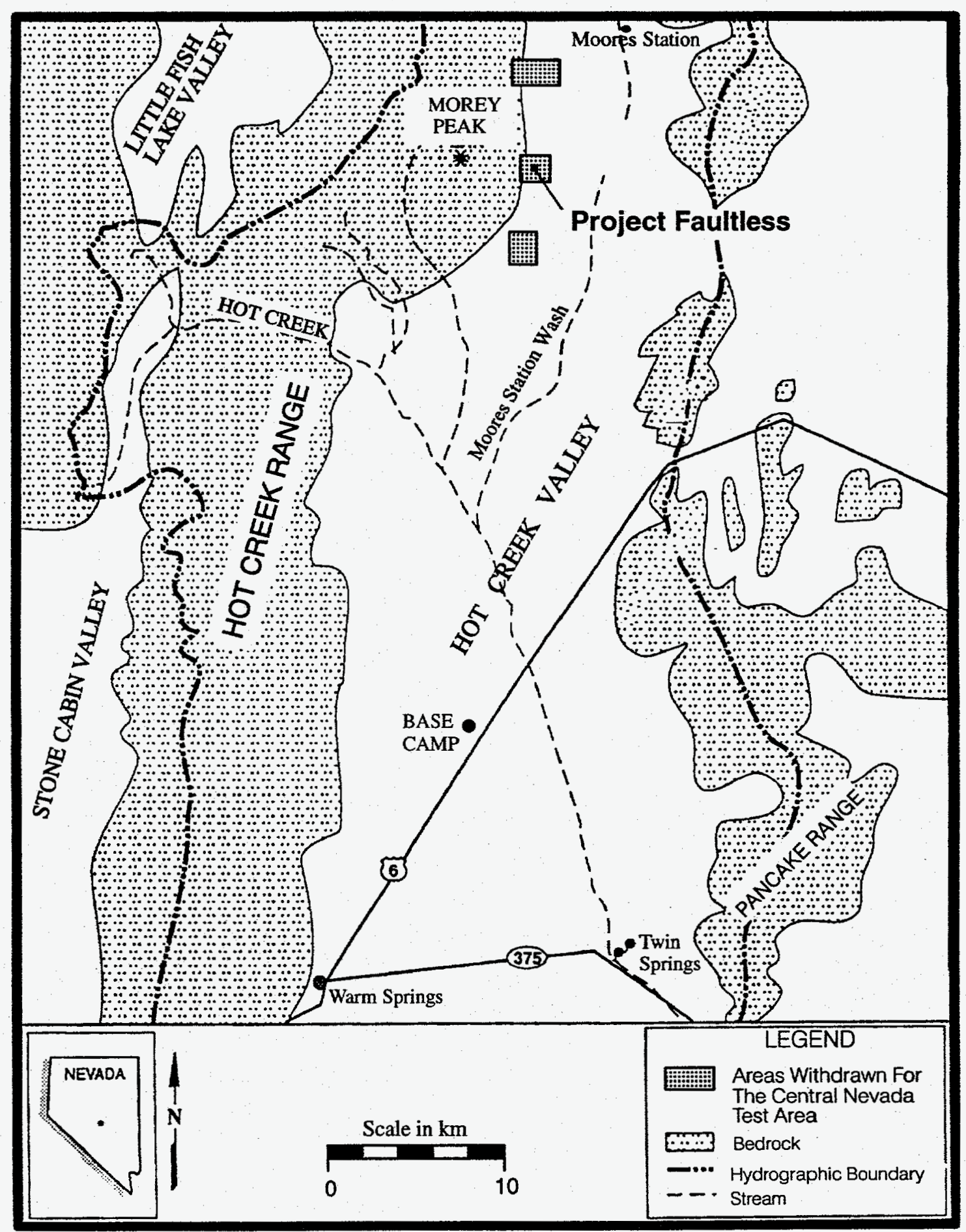

Figure 1. Location of the three land areas withdrawn for the Central Nevada Test Area in Hot Creek Valley. The Project Faultless test was conducted in the middle block. 
subsurface flow out of the valley. Little information is available on water flow in the bedrock aquifers of the valley. Differences in hydraulic head, water chemistry, and temperature suggest that the alluvium and volcanics are distinct water-bearing zones (Dinwiddie and Schroder, 1971). Though vertical head gradients were detected, Dinwiddie and Schroder (1971) concluded that vertical movement is slow relative to lateral flow, based on the anisotropy of hydraulic properties.

The Faultless detonation occurred in the tuffaceous sediment section, but the resultant cavity and chimney extended into the overlying alluvium. The water table in the chimney was depressed by the nuclear test and was essentially static from 1969 to 1974 (Thordarson, 1987). At the end of 1974 , the water level began to rise as the rubble chimney filled. Thordarson (1987) estimated that the pre-event water level of $168 \mathrm{~m}$ below ground surface would be reached between 1993 and 2018 .

\section{METHODS}

Three boreholes were initially used to investigate the status of contaminant migration from the Faultless event and evaluate monitoring efforts. These were HTH-1, HTH-2, and UC-1-P-2SR (the postshot hole) (Figure 2). During the study, an abandoned postshot hole numbered UC-1-P-1S was located and added for evaluation. To obtain the most information possible from this limited set of boreholes, hydrologic logging was performed, water samples were collected, and measurements of water level were made.

\section{Chemical Logging}

The Chem-tool is a chemical logging tool recently developed by the Desert Research Institute, that has the capability of measuring temperature, specific conductance, and $\mathrm{pH}$ in deep wells. It consists of several off-the-shelf components that are integrated into a system that is used to $\log$ specific chemical parameters in a borehole. The components include the microprocessor module, communication module, power module, amplifier module, and probe module (Figure 3). The modules are encapsulated in a stainless-steel pressure vessel designed to withstand pressures of up to $6000 \mathrm{kN} / \mathrm{m}^{2}$ (610 $\mathrm{m}$ of pressure head). The pressure vessel consists of two separate pressure containment sections. The primary section houses the communication, power, and microprocessor modules. This section is separated by the isolator bulkhead from the lower section which contains the probe and amplifier modules. The electrical signals and power are transferred through the isolator bulkhead by a high-pressure, 14-conductor feedthrough. The overall length of the Chem-tool is $132.1 \mathrm{~cm}$ and it has a diameter of $10.16 \mathrm{~cm}$.

The temperature sensor consists of a Fenwal model 124-503JAJ-QO1 glass bead, precision thermistor with a $30,000 \mathrm{ohm}, 0.1$ percent tolerance, precision completion resistor. The thermistor was calibrated against a certified mercury thermometer by immersing both sensors in an insulated water bath. The first calibration was performed by the addition of warm water which was allowed to cool to room temperature over an eight-hour period while temperature and millivolt readings were made. The next calibration was conducted in a similar manner with ice water slowly warming to room temperature. The temperature and millivolt data were plotted and a fourth-order polynomial computed that is used in the microprocessor to convert millivolt readings to a temperature. The 


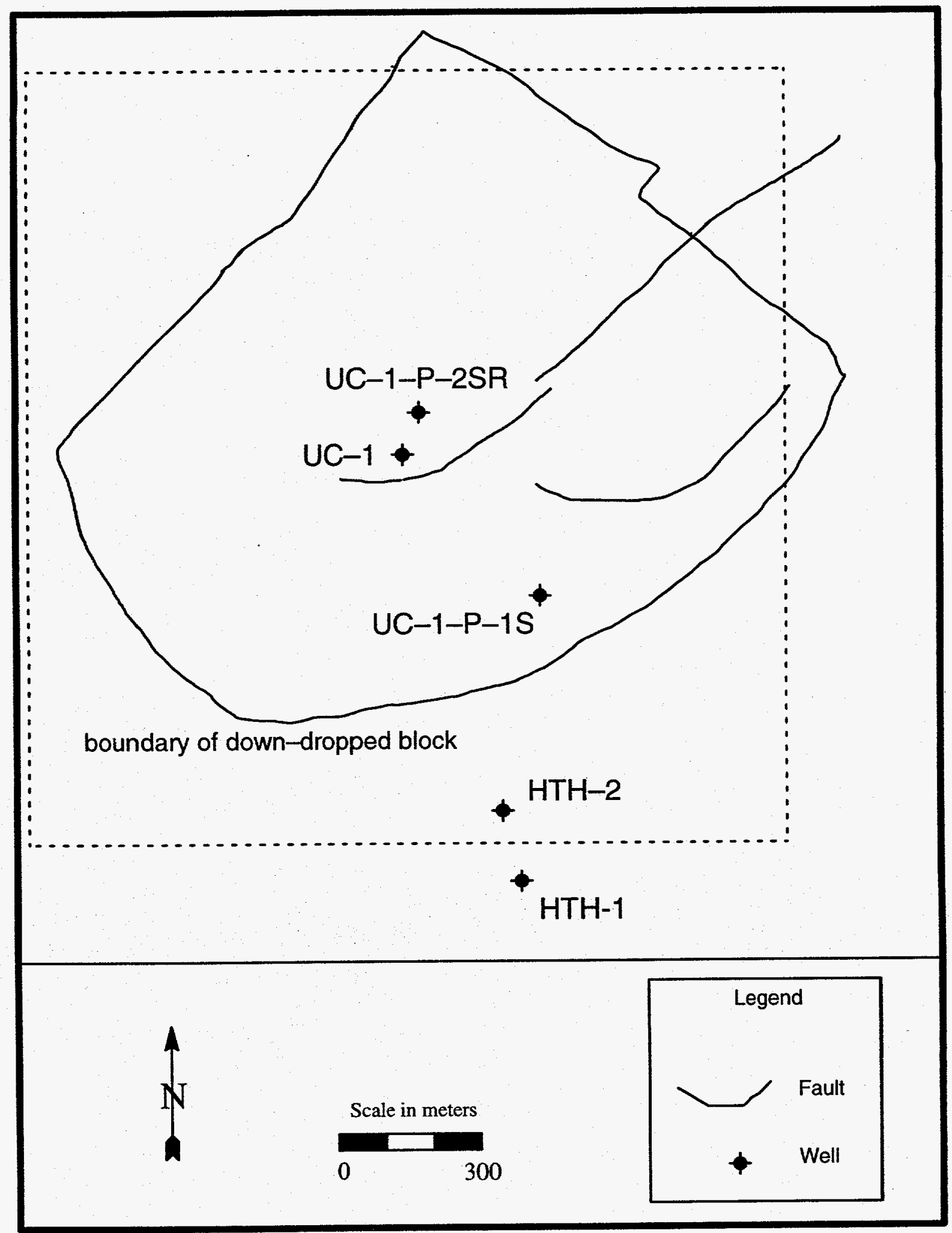

Figure 2. Location of wells near the Faultless Site at the Central Nevada Test Area. UC-1 was the emplacement hole for the nuclear device. For the location of the site within Hot Creek Valley, please see Figure 1. The square is the approximate boundary of the one-square-mile area withdrawn for the test, as shown on Figure 1. 


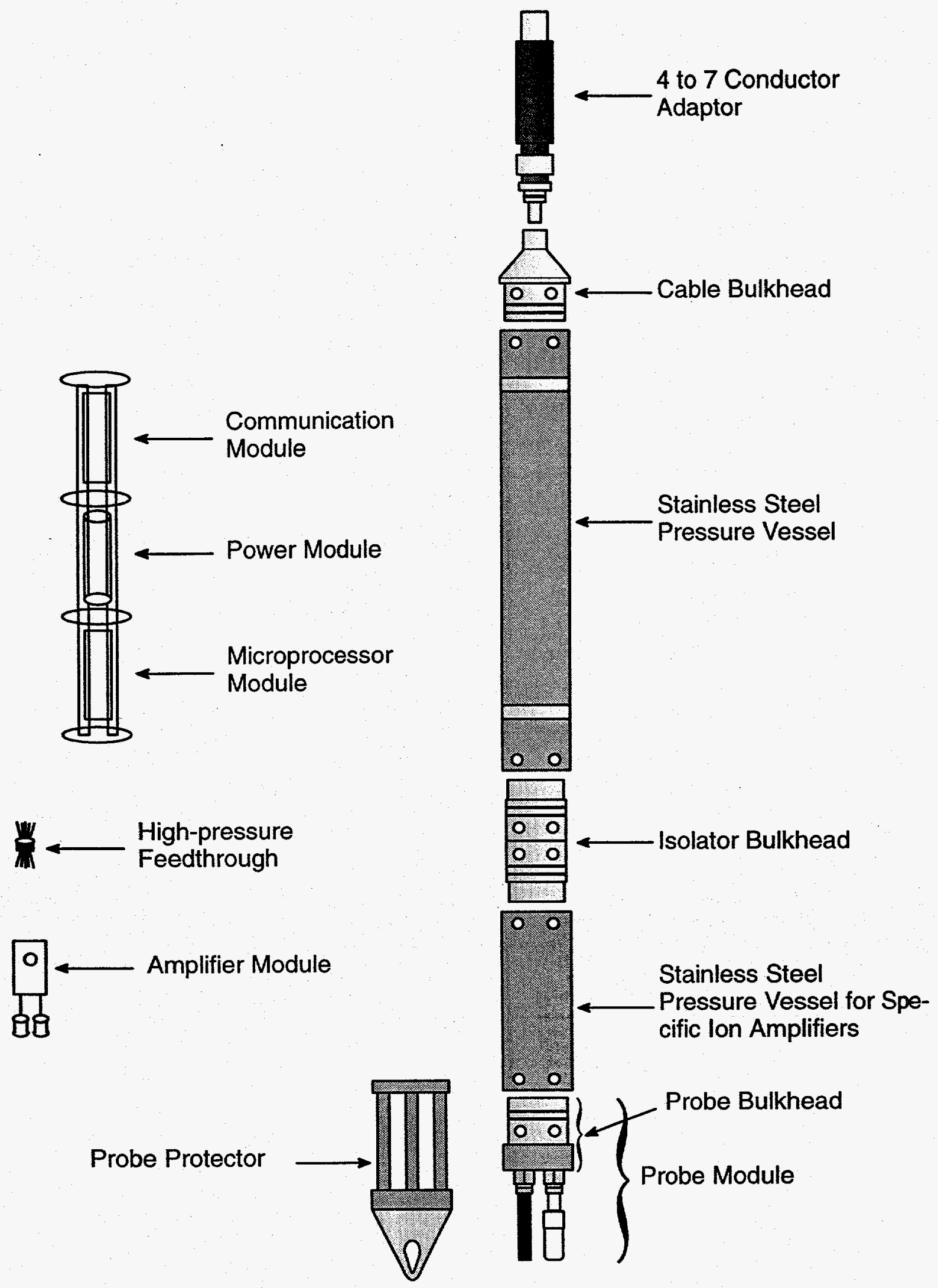

Figure 3. Schematic diagram of the Chem-tool. 
resolution of the temperature measurements is $0.015^{\circ} \mathrm{C}$. The specific conductance sensor is a YSI model 3417 sensor that is potted into a Cajon Hollow Hex High-Pressure Fitting ${ }^{(m)}$. The sensor has a cell constant of 1 and is measured with an alternating current excitation to eliminate sensor polarization. It is calibrated in the field prior to each use with laboratory standards bracketing the expected conductivity range. The resolution of the electrical conductivity measurements is $5 \mu \mathrm{S} / \mathrm{cm}$ at $25^{\circ} \mathrm{C}$. The $\mathrm{pH}$ sensor was manufactured by Innovative Sensors, Inc. using a standard jell-filled combination $\mathrm{pH}$ sensor suitable for high-pressure application, potted into a Cajon high-pressure fitting. The signal from the probe is amplified and transmitted to the microprocessor through a current loop. The $\mathrm{pH}$ probe is calibrated in the field prior to each use with laboratory standards bracketing the expected $\mathrm{pH}$ range. The resolution of the $\mathrm{pH}$ measurements is 0.1 units. Discrete measurements are made with the logging tool every second; therefore, at a logging rate of $6.1 \mathrm{~m}$ per minute, a measurement is made every $10 \mathrm{~cm}$. These finely spaced measurements allow the detection of variations in water chemistry, which may be the result of water from different aquifers mixing in the borehole.

\section{Thermal Flow Logging}

The thermal flowmeter (TFM) is a hydrologic logging tool that is designed to measure the vertical fluid flow in a borehole (Lyles, in press). The basic principle of the TFM is to measure the direction and speed of a heat pulse generated between two thermistors lowered in a well. The TFM is $6.4 \mathrm{~cm}$ in diameter, approximately $120 \mathrm{~cm}$ long, and weighs approximately $4.5 \mathrm{~kg}$. Electronic circuitry is housed in the top of the logging tool and a flow-through cell is located near the bottom of the tool (Figure 4). The downhole electronics receive electricity and signals from the TFM surface module (located in the logging vehicle) via a multi-conductor electric logging cable. The downhole electronics control the charge/discharge of capacitors used to emit pulses of energy that heat the water flowing through a heating grid in the TFM's flow-through cell, and control measurement of the heat propagation at thermistors positioned near the top and bottom of the flow-through cell; the heat-pulse response time is sent to the surface module as a 1 to 35 kilo-Hertz frequency. The signal is transmitted as a frequency rather than an analog voltage to eliminate errors associated with long cable lengths. The surface module converts this frequency into a voltage, which is sent to a plotter, datalogger, and/or computer.

Discharge of the capacitors is controlled via the surface module. When the capacitors are discharged, $100 \mathrm{VDC}$ (volts direct current) is sent to a heat grid made of nickel chromium wire which has a nominal resistance of approximately $10 \mathrm{ohms}$. Ninety percent of the capacitors' energy is sent to the heat grid in approximately 1 millisecond, nearly instantaneously. The heat grid is designed to heat a sheet of water within the flow-through cell as uniformly as possible. Glass-bead thermistors are positioned approximately $2 \mathrm{~cm}$ above and below the heat grid; the thermistors have a response time of about 0.5 seconds and have a resolution of $0.001^{\circ} \mathrm{C}$. The heat plume radiates upward and downward; under no-flow conditions, the heat-pulse is received by the top thermistor first due to buoyancy effects (after approximately $60 \mathrm{sec}$ ), then it is received by the bottom thermistor (after approximately $90 \mathrm{sec}$ ). The data are shown as differential temperature (millivolts) between the two thermistors (top minus bottom) on the $y$-axis and as heat-pulse response time (seconds) on the $x$-axis 


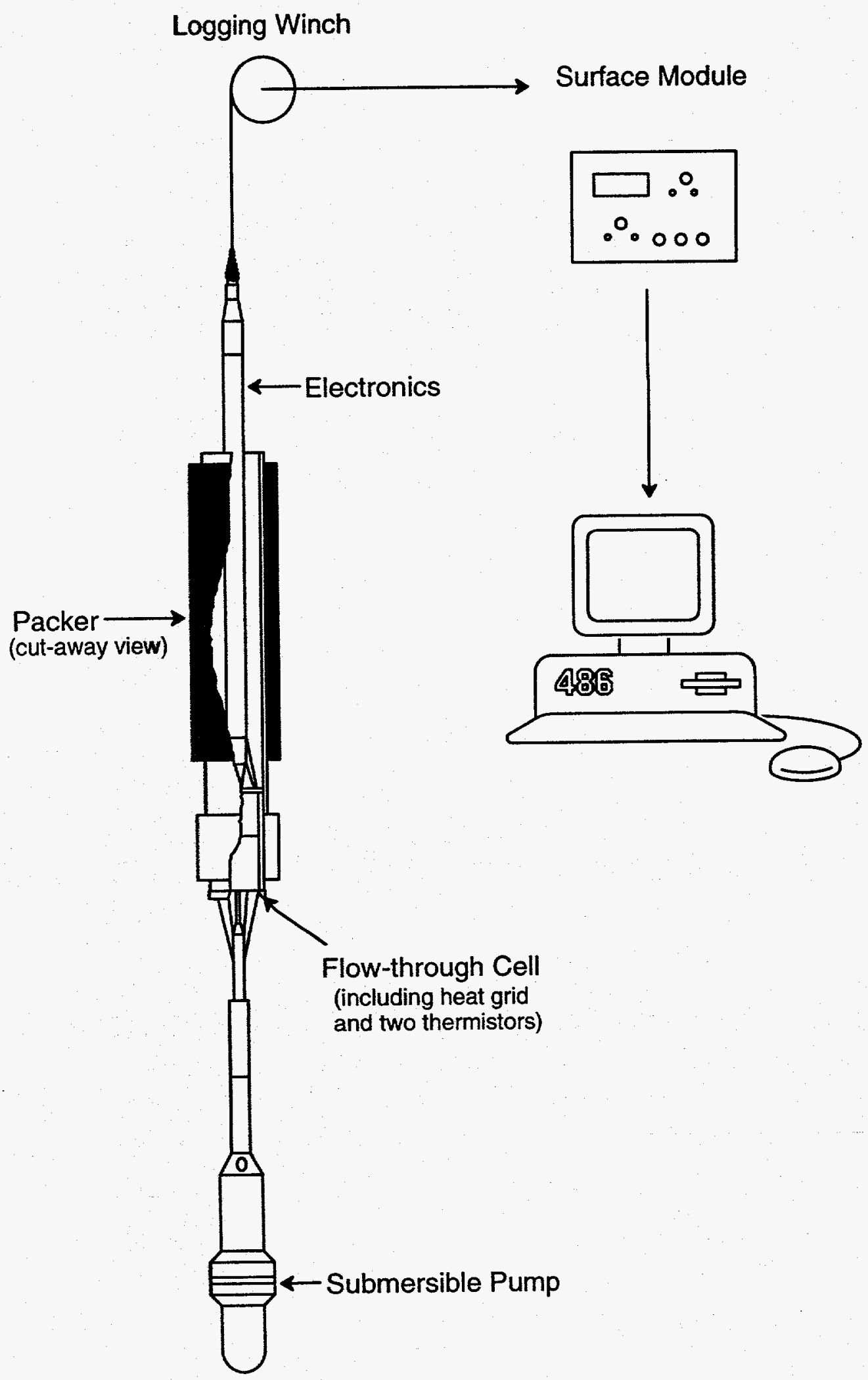

Figure 4. Schematic diagram of the thermal flowmeter. From Lyles (in press). 
(Figure 5). If a peak (sharply increasing positive values) is received first, then the water is flowing upward through the flow cell; conversely, if a trough is received first, then the flow direction is downward. After the TFM is calibrated, the flow rate can be computed from the TFM heat-pulse response time.

The TFM directly measures the rate of fluid flowing through the TFM's flow-through cell, which, when a packer seals the rest of the area, equals the rate in the borehole. Knowing the flow rate in the cell and borehole diameter, the fluid velocity in the borehole can be computed using the equation:

$$
V=1273.24 \frac{Q}{D^{2}}
$$

where $\mathrm{V}=$ velocity $(\mathrm{cm} / \mathrm{min}), \mathrm{Q}=$ flow rate $(\mathrm{l} / \mathrm{min})$, and $\mathrm{D}=$ well diameter $(\mathrm{cm})$. The TFM is capable of measuring flow rates down to $0.08 \mathrm{l} / \mathrm{min}$ (Lyles, in press).

\section{Sample Collection}

Water samples for chemical and isotopic analysis were collected from July 27 to 31,1992 , from August 4 to 7, 1992, from May 19 to 24, 1993 and from November 13 to 17, 1993. Water samples were collected in a two-liter capacity motorized discrete sampler. The sampler was cleaned with deionized water and the intake closed before sending it downhole to the desired depth. The sampling port was then opened and allowed to fill for approximately 10 minutes. The sampler was then closed and retrieved to the surface. Temperature, $\mathrm{EC}, \mathrm{pH}$, and alkalinity were determined immediately after sample collection. The sample was split according to the following: one liter in a glass bottle with a polyseal lid for enriched tritium analysis, $30 \mathrm{ml}$ in a glass bottle with a polyseal lid for stable oxygen and hydrogen isotope analysis, $500 \mathrm{ml}$ in a plastic bottle for anion analysis, and $250 \mathrm{ml}$ filtered through a $0.45 \mu$ filter and acidified to a $\mathrm{pH}$ less than 2 with nitric acid in a plastic bottle for cation analysis. The anion and cation samples were stored and transported on ice to the laboratory.

\section{SITE INVESTIGATION}

Vertical temperature gradients beneath the surface (geothermal gradients) are primarily a function of the thermal conductivity of rocks, though they can be modified by natural groundwater flow. In an area of similar stratigraphy and hydrology, the geothermal gradient will be relatively constant from one location to another. Once a well is drilled, a conduit for potential vertical water movement and heat transfer is created and deviations from the local geothermal gradient can occur. Under static, or very slow, flow conditions, a temperature log in a well will approximate the geothermal gradient; conversely, if there are high flow rates in the well, no gradient will be apparent. Thus, comparisons between individual temperature logs and the estimated geothermal gradient can be used to detect water movement in boreholes and the relationship between intercepted water-bearing units. At the Faultless site, this analysis is somewhat more difficult because of the artificially introduced point heat source from the Faultless event and the presence of directionally drilled holes that slant toward that heat source. 

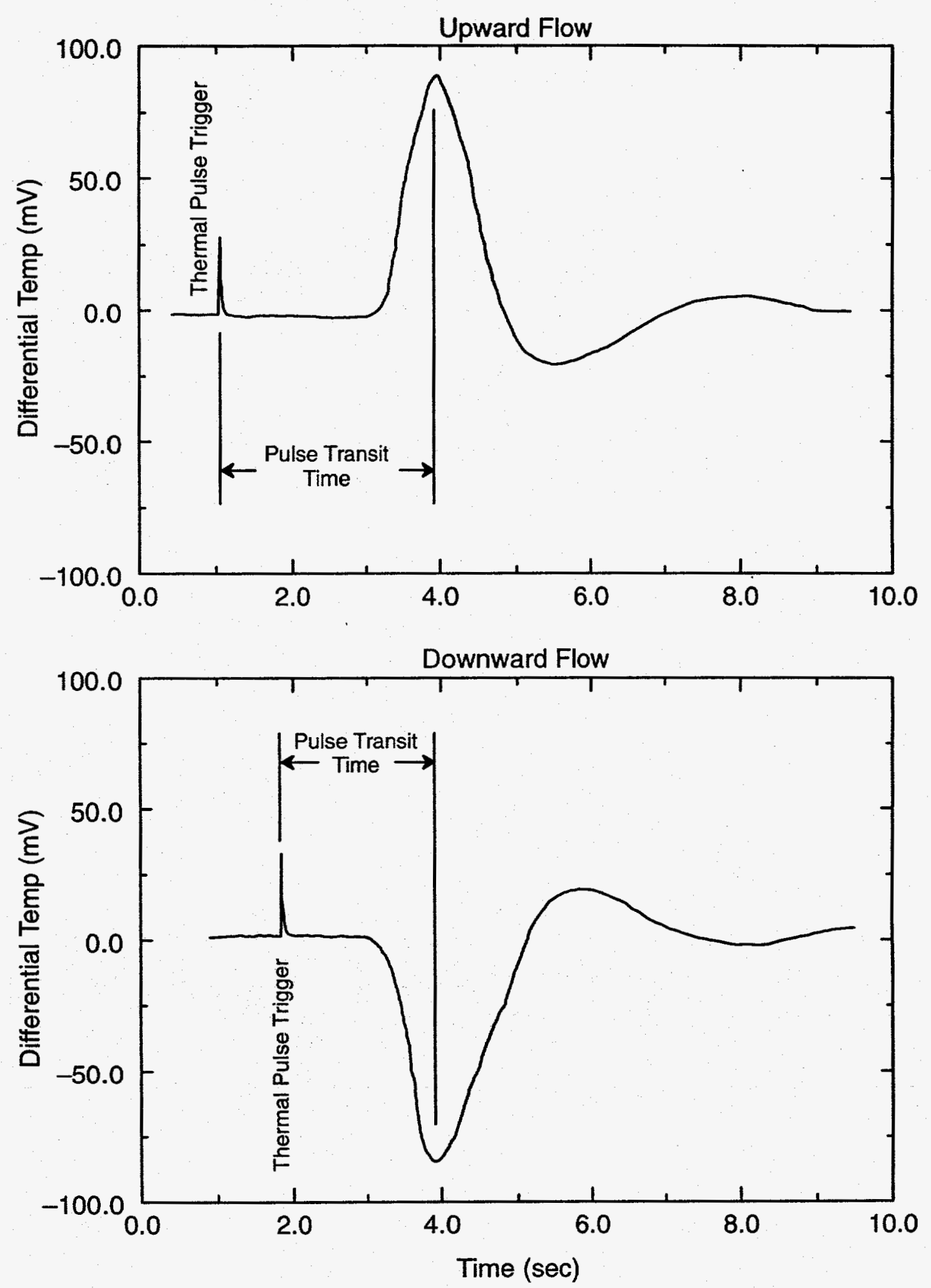

Figure 5. Typical heat-pulse responses from the thermal flowmeter. Differential temperature is the top thermistor temperature minus the bottom thermistor temperature. Upward flow is indicated by a peak-type response, downward flow is indicated by a trough-type response. From Lyles (in press). 
The geothermal gradient in the Faultless area (Figure 6) was estimated from the temperature profile in a section of well UC-1-P-2SR that was determined to have no flow based on TFM measurements. The estimated gradient is $0.032^{\circ} \mathrm{C} / \mathrm{m}$ and deviations from this thermal gradient line were used for the analysis of logs from individual wells. Using top- and bottom-hole temperatures was deemed inappropriate for determining the gradient because most of the wells are not accessible for logging tools to their drilled depth, making fluid flow from depth possible. One well, HTH-2 is accessible close to its drilled depth (300.7 $\mathrm{m}$ versus $304.8 \mathrm{~m}$ drilled), but indications of strong downward flow and a large temperature gradient at the very bottom of the well suggest that the temperature profile in HTH-2 is perturbed from the in situ gradient. The geothermal gradient is believed to be similar in both the alluvium and volcanic units because the alluvium is comprised principally of volcanic material (Hoover, 1968).

\section{HTH-1}

HTH-1 is a hydrologic test hole that was drilled to a depth of $1128.9 \mathrm{~m}$ and completed with $0.244-\mathrm{m}$ casing that was cemented in place from the bottom of the hole to $11.3 \mathrm{~m}$ below the land surface. The casing was then gun-perforated with two shots per foot at the intervals shown in Figure 7. An obstruction developed in the hole after the Faultless event (possibly due to sheared or deformed casing) and the borehole is presently accessible only to a depth of $849.7 \mathrm{~m}$. Lithologies encountered in HTH-1 include $728.4 \mathrm{~m}$ of alluvium followed by $23.8 \mathrm{~m}$ of densely welded tuff and $376.7 \mathrm{~m}$ of tuffaceous sediments.

Chemical logging was performed in HTH-1 on May 19 and November 14, 1993. The results of the May logging are shown graphically in Figure 7. The temperature log shows a curvilinear rise in temperature from $18.1^{\circ} \mathrm{C}$ at the water surface to $23.4^{\circ} \mathrm{C}$ at $248.4 \mathrm{~m}$. The log for the remainder of the well shows a more gradual increase in temperature of $0.028^{\circ} \mathrm{C} / \mathrm{m}$, which is slightly lower than the estimated geothermal gradient for this area. Although this increasing trend is somewhat constant, small perturbations in the temperature log do exist. The $\mathrm{pH} \log$ shows a similar, but inverse, trend as compared to the temperature log in the upper portion of the borehole. The $\mathrm{pH}$ decreases sharply from the water surface to $248 \mathrm{~m}$, then decreases less sharply to $730 \mathrm{~m}$. At $730 \mathrm{~m}$, a sharp decrease of $0.2 \mathrm{pH}$ units (the resolution of the $\mathrm{pH}$ measurements is 0.1 units) occurred over a 14-m interval. The $\mathrm{pH}$ continued to decrease gradually for the remainder of the open borehole. The conductivity $\log$ indicates a steady, small increase in specific conductance from 530 to $585 \mu \mathrm{S} / \mathrm{cm}$ (the tool has a conductivity resolution of $5 \mu \mathrm{S} / \mathrm{cm} @ 25^{\circ} \mathrm{C}$ ) over most of the well length. Near the bottom, however, the EC increased sharply by approximately $50 \mu \mathrm{S}$ over the interval from 812 to $825 \mathrm{~m}$.

Although the EC and pH logs run in November 1993 look similar to the logs performed in May, differences between the temperature logs indicate that the flow regime in the borehole has changed (Figure 8). The largest deviation occurs at $735 \mathrm{~m}$ within the perforations in the welded tuff, where a temperature perturbation was observed on the May temperature log. The perturbation on the November temperature $\log$ is more pronounced than on the May log and cooler by approximately $0.25^{\circ} \mathrm{C}$. Below $735 \mathrm{~m}$, the November temperature log is consistently cooler by approximately $0.07^{\circ} \mathrm{C}$ (the Chem-tool has a temperature resolution of $0.015^{\circ} \mathrm{C}$ ). At $704 \mathrm{~m}$, both temperature logs 


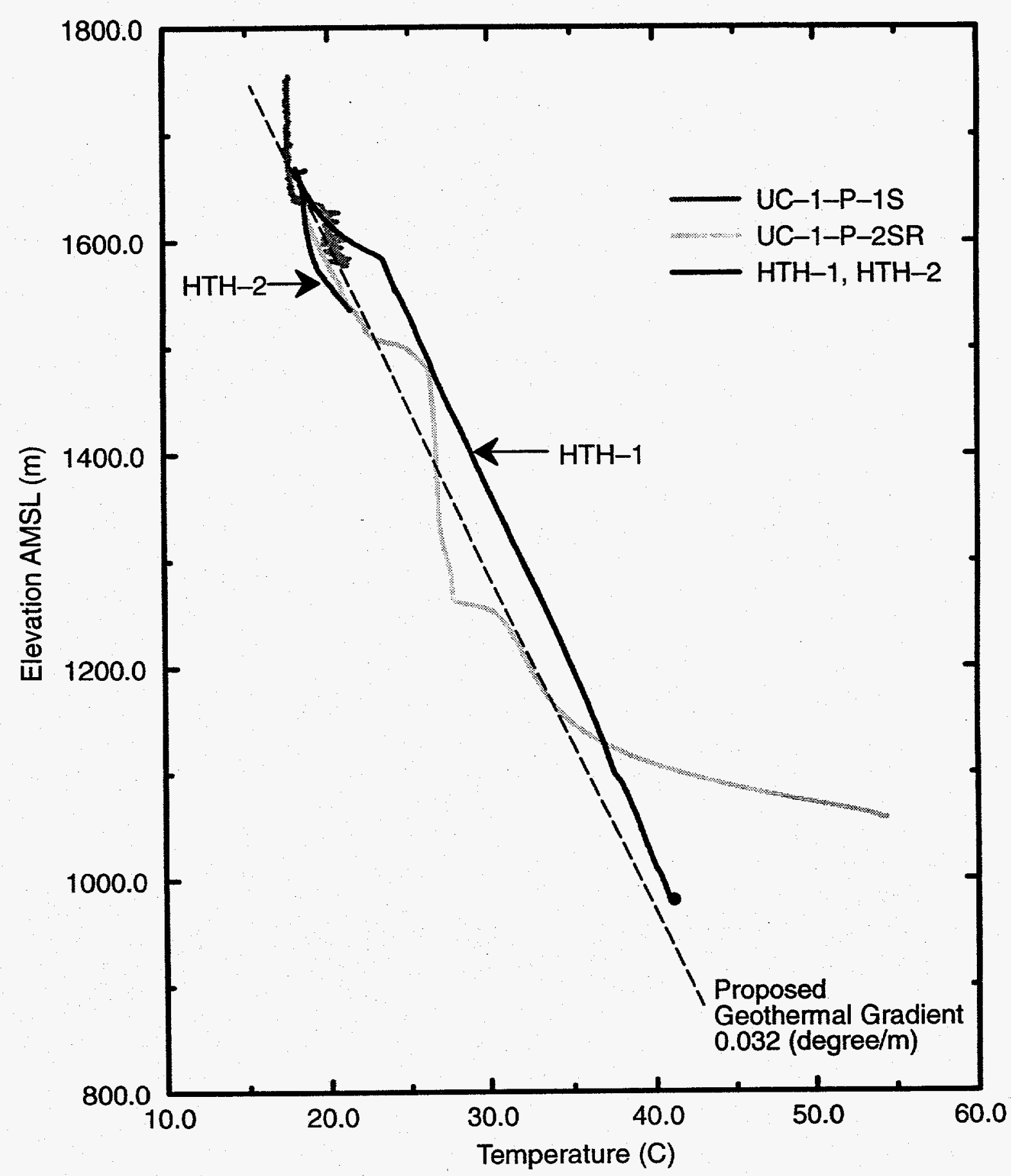

Figure 6. Temperature logs from boreholes at the Faultless site, with the proposed local geothermal gradient. The gradient is based on the temperature profile in the region centered on $1200 \mathrm{~m}$ elevation in UC-1-P-2SR. This zone was determined to have no flow in the borehole by TFM measurements. 


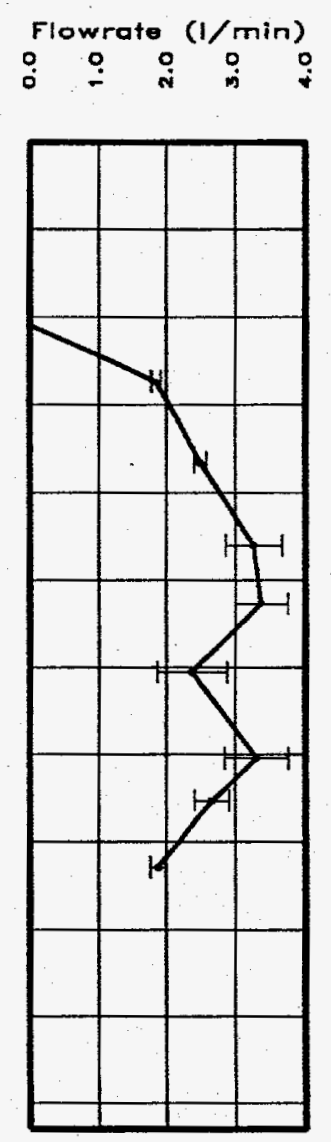

Flowrate (1/min)

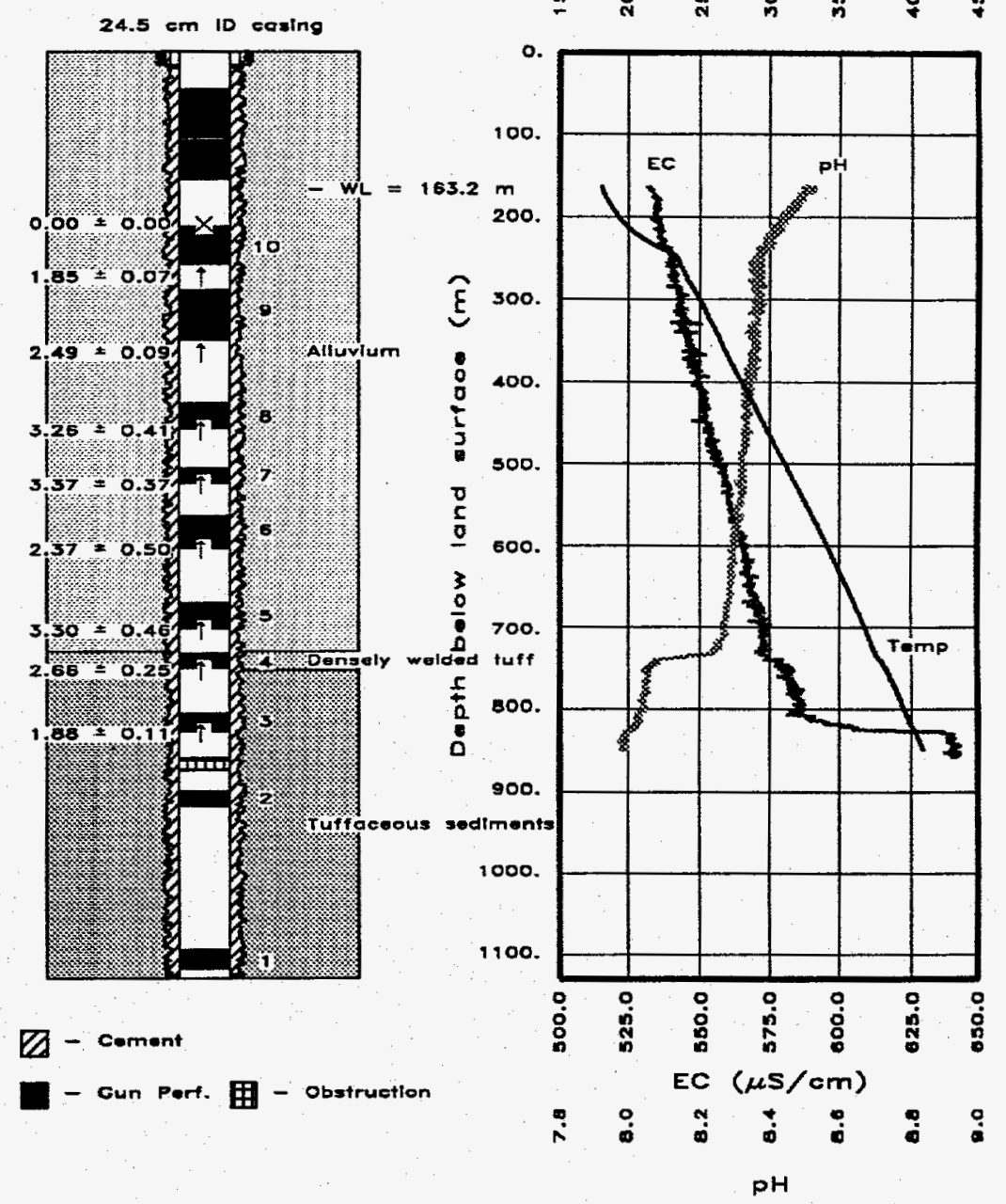

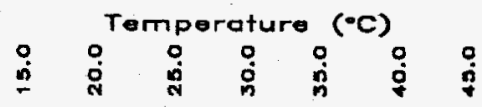

Figure 7. Borehole completion and hydrologic logs (run in May 1993) from HTH-1. Vertical water flow in the borehole is plotted as function of depth on the left and annotated on the well schematic (arrows indicate flow direction), and temperature, $\mathrm{EC}$ and $\mathrm{pH}$ measurements are plotted on the right. Upward flow was measured throughout the well, exiting through the upper two screens (screens 9 and 10). Inflow from the densely welded tuff at screen 4 is marked by a large change in $\mathrm{pH}$ and $\mathrm{EC}$ and small change in temperature. 


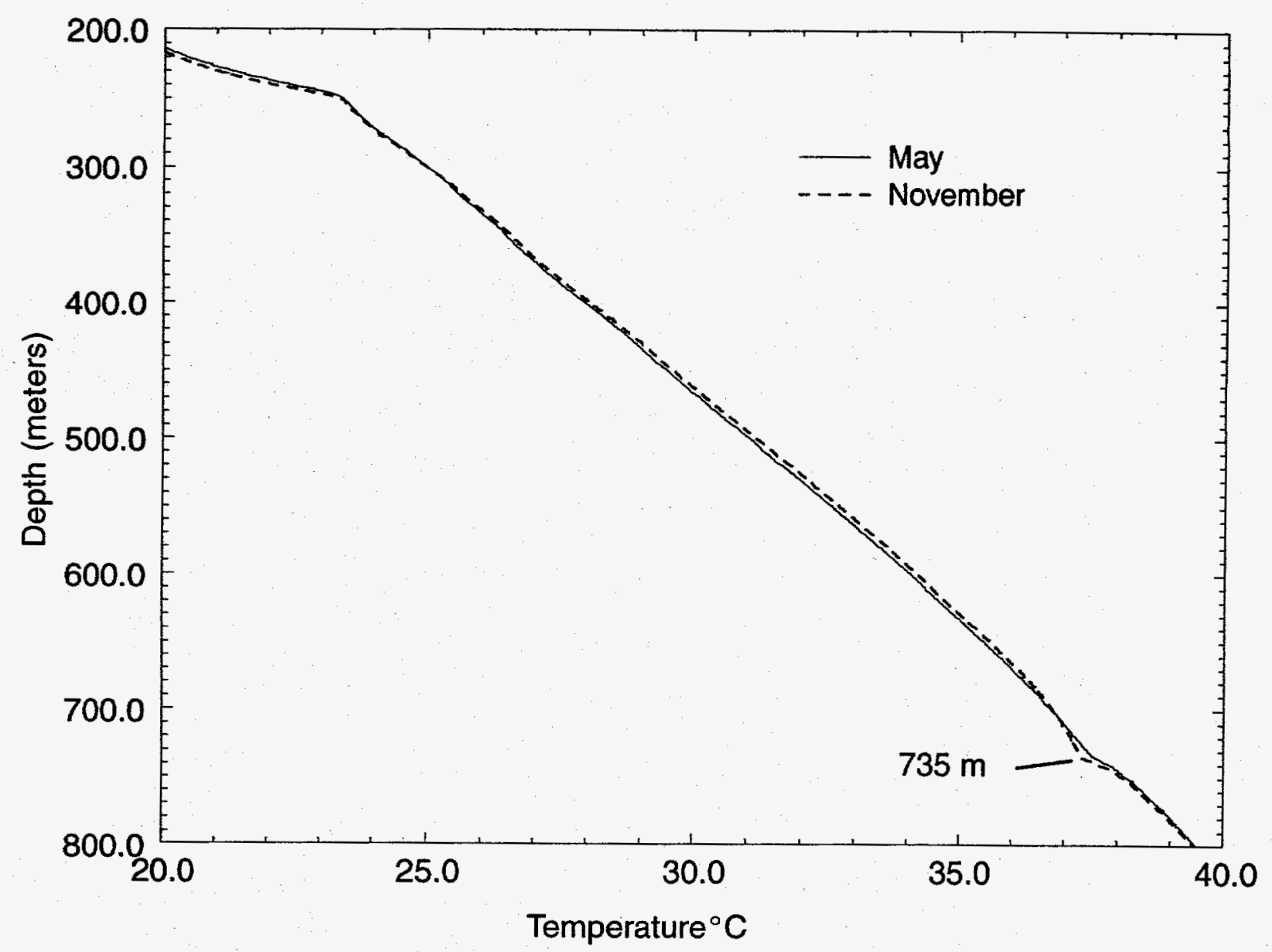

Figure 8. Comparison of May and November, 1993, Temperature Logs from HTH-1.

recorded the same temperature of $36.9^{\circ} \mathrm{C}$. Above this point, the November log is consistently warmer by approximately $0.15^{\circ} \mathrm{C}$ until the next temperature crossover point is reached at $303 \mathrm{~m}$. The temperatures from the two logs are very similar over the interval of $251 \mathrm{~m}$ to $303 \mathrm{~m}$. In the remaining saturated portion of the borehole, the November temperature log is consistently cooler by $0.2^{\circ} \mathrm{C}$.

The TFM was used to measure the fluid velocity at nine locations in HTH-1 on May 20, 1993. Measurements were made between each perforated interval, above the top interval and below the bottom of the last accessible interval. Measurements were made by inflating a packer which diverted all flow through the tool. The results from these discrete measurements are shown in Figure 7. These data suggest that the majority of the water enters the well in the lower tuffaceous zones, travels upward, then exits the borehole in the upper alluvial zones. Although the measurements show water loss through the fifth set of perforations and gain through the sixth, the relatively high error associated with those particular measurements (note error bars on Figure 7) and lack of response in the temperature, $\mathrm{pH}$, or EC logs, make that interpretation uncertain. 
Water samples were collected from HTH-1 on July 28 and 29, 1992, May 20, 1993, and November 14, 1993. The samples were collected at the middle of each screened zone and at the bottom of the accessible hole. The water chemistry is remarkably similar at all depths in the well (Table 1), though there is a small increase in salinity at the bottom of the well (across from the bottom accessible screen and in the bottom-hole sample). Despite the salinity differences, all of the HTH-1 samples have essentially identical ion ratios, and can be characterized as $\mathrm{Na}-\mathrm{HCO}_{3}$ water (Figure 9). The stable isotopic composition is also uniform at $\delta^{18} \mathrm{O}$ of -15.5 to $-15.4 \%$ and $\delta \mathrm{D}$ of -118 to $-117 \% \circ$ (Table 1 and Figure 10 ). The precision of the measurements is $\pm 0.2 \% \circ$ in $\delta^{18} \mathrm{O}$ and $\pm 1 \% \circ$ in $\delta D$. Eight samples were analyzed for tritium $\left({ }^{3} \mathrm{H}\right)$. All of the samples from 1993 and the 1992 sample from $740 \mathrm{~m}$ were below the detection limit of $10 \mathrm{pCi} /$. The remaining 1992 samples contained 33 $\pm 1 \mathrm{pCi} / 1$ at $320 \mathrm{~m}$ and $214 \pm 7 \mathrm{pCi} / 1$ at $236 \mathrm{~m}$.

\section{Interpretation of HTH-1 Data}

The water in HTH-1 is derived from the lower portion of the borehole. The largest measured inflow enters the borehole from below the restriction in the casing and was measured at $1.88 \mathrm{l} / \mathrm{min}$. The water flows upward and mixes with a lesser flow of $0.791 / \mathrm{min}$ from the third set of perforations (perforations are numbered from bottom to top, according to Dinwiddie and Schroder, 1971), which has a slightly lower concentration of dissolved constituents, though a similar chemical composition. The mixing of these waters is evident from measurements with the TFM and the conductivity log, which dropped from $630 \mu \mathrm{S}$ to $587 \mu \mathrm{S}$ over the screened interval. This mixture of water continues to move upward, then mixes with inflowing water from the fourth set of perforations, across the densely welded tuff. The TFM measurements above and below this set of perforations indicate that $0.63 \mathrm{l} / \mathrm{min}$ is entering the well from this zone. Inflow from this zone is also indicated by a slight perturbation in the temperature log as well as a rapid increase in $\mathrm{pH}$ near these perforations. Again, the general water chemistry is the same, but the added water is slightly lower in salinity, which can be seen in the conductivity log and the chemical analyses. The water rises up the borehole and exits through the eighth, ninth, and tenth perforated intervals at rates of $0.77,0.64$, and $1.851 / \mathrm{min}$, respectively. The TFM also measured outflow through the fifth set of perforations and inflow through the sixth set of perforations of equal portions of about $0.951 / \mathrm{min}$.

The water chemistry also indicates that the volcanic units are the common source of water in the well. When Dinwiddie and Schroder (1971) collected samples during testing in HTH-1, the upper screens produced water with a lower salinity, higher calcium and lower sodium concentrations, more similar to the alluvial water sampled by DRI from HTH-2. By 1992, samples collected across from every screened interval were virtually identical $\mathrm{Na}-\mathrm{HCO}_{3}$ water. The chemical log shows that temperature-corrected EC increases gradually with depth, with a sharp increase of $50 \mu \mathrm{S} / \mathrm{cm}$ between the bottom of the accessible hole and the welded tuff unit. A comparable increase in conductivity was found for a sample collected from this zone, but there was no difference in ion ratios, suggesting similar water-mineral reactions but with a longer residence time. Though the stable isotopic composition of precipitation in the local area is not known, comparison with groundwater samples from HTH-2 and precipitation from the Nevada Test Site (NTS) suggests that the water sampled from HTH-1 was recharged under a cooler climate, probably during the last 
Table 1. Chemical and Isotopic Analyses of Groundwater Samples from the Faultless Site. All units are $\mathrm{mg} / \mathrm{l}$ unless noted otherwise.

\begin{tabular}{|c|c|c|c|c|c|c|c|c|c|c|c|c|c|c|c|c|c|c|c|}
\hline Well & $\begin{array}{l}\text { Depth } \\
\text { (m) }\end{array}$ & Date & $\begin{array}{c}\mathrm{T} \\
\left({ }^{\circ} \mathrm{C}\right)\end{array}$ & $\begin{array}{c}\mathrm{pH}^{1} \\
\text { (S.U.) }\end{array}$ & $\begin{array}{c}\mathrm{EC}^{1} \\
(\mu \mathrm{S} / \mathrm{cm})\end{array}$ & $\mathrm{SiO}_{2}$ & $\mathrm{Ca}$ & $\mathrm{Mg}$ & $\mathrm{Na}$ & $\mathbf{K}$ & $\mathrm{Cl}$ & $\mathrm{SO}_{4}$ & $\mathrm{HCO}_{3}{ }^{1}$ & $\mathrm{CO}_{3}$ & $\mathrm{NO}_{3}$ & $F$ & $\begin{array}{l}\delta^{18} \mathrm{O} \\
(\%))\end{array}$ & $\begin{array}{l}\delta \mathrm{D} \\
(\% 0)\end{array}$ & $\begin{array}{c}{ }^{3} \mathrm{H} \\
(\mathrm{pCi} / \mathrm{L})\end{array}$ \\
\hline HTH-1 & 183 & 14-Nov-93 & & & & & & & & & & & & & & & & & $<10$ \\
\hline HTH-1 & 236 & 28-Jul-92 & 23 & $8.23 / 8.40$ & $536 / 545$ & 55.4 & 3.28 & 0.10 & 126 & 1.52 & 16.7 & 33.5 & $189 / 238$ & 4.1 & $<.04$ & 9.4 & -15.4 & -117 & $214 \pm 7$ \\
\hline HTH-1 & 236 & 14-Nov-93 & & & & & & & & & & & & & & & & & $<10$ \\
\hline HTH-1 & 274 & 14-Nov-93 & & & & & & & & & & & & & & & & & $<10$ \\
\hline HTH-1 & 320 & 28-Jul-92 & 26 & $8.35 / 8.31$ & $519 / 539$ & 56.0 & 3.10 & 0.07 & 125 & 1.39 & 16.8 & 33.4 & $217 / 243$ & 0.6 & $<.04$ & 10.4 & -15.4 & -117 & $33 \pm 1$ \\
\hline HTH-1 & 320 & 14-Nov-93 & & & & & & & & & & & & & & & & & $<10$ \\
\hline HTH-1 & 442 & 28-Jul-92 & 26 & $8.38 / 8.30$ & $542 / 542$ & 56.5 & 3.53 & 0.07 & 125 & 1.37 & 16.8 & 33.5 & $211 / 244$ & 0.4 & $<.04$ & 10.4 & -15.4 & -117 & \\
\hline HTH-1 & 501 & 14-Nov-93 & & & & & & & & & & & & & & & & & $<10$ \\
\hline HTH-1 & 515 & 28-Jul-92 & 26 & $8.27 / 8.43$ & $516 / 546$ & 57.5 & 4.51 & 0.09 & 125 & 1.37 & 16.8 & 33.4 & $220 / 238$ & 4.7 & $<.04$ & 10.5 & -15.4 & -117 & \\
\hline HTH-1 & 578 & 28-Jul-92 & 25 & $8.34 / 8.32$ & $524 / 540$ & 56.8 & 3.22 & 0.07 & 127 & 1.37 & 16.8 & 33.1 & $211 / 242$ & 0.9 & $<.04$ & 10.5 & -15.4 & -118 & \\
\hline HTH-1 & 686 & 28-Jul-92 & 24 & $8.44 / 8.40$ & $516 / 543$ & 57.1 & 3.06 & 0.05 & 125 & 1.42 & 17.0 & 33.5 & $226 / 237$ & 3.6 & $<.04$ & 10.5 & -15.5 & -118 & \\
\hline HTH-1 & 741 & 29-Jul-92 & 24.5 & $8.25 / 8.27$ & $509 / 548$ & 64.3 & 2.95 & 0.06 & 128 & 1.55 & 18.2 & 33.4 & $199 / 247$ & & $<.04$ & 9.4 & -15.4 & -118 & $<10$ \\
\hline HTH-1 & 815 & 29-Jul-92 & 26.5 & $8.15 / 8.24$ & $508 / 561$ & 66.2 & 2.93 & 0.07 & 129 & 1.55 & 19.1 & 34.5 & $205 / 249$ & & $<.04$ & 10.4 & -15.5 & -118 & \\
\hline HTH-1 & 853 & 20-May-93 & & 8.17 & 588 & 68.4 & 3.0 & 0.1 & 134 & 2.16 & 21.4 & 38.9 & 261 & & $<.04$ & & & & \\
\hline HTH-2 & 174 & 22-May-93 & & 8.01 & 287 & 28.3 & 36.9 & 5.24 & 19.1 & 1.44 & 4.1 & 0.66 & 177 & & 3.19 & & -14.1 & -107 & $<10$ \\
\hline HTH-2 & 198 & 6-Aug-92 & & 8.27 & 304 & 28.9 & 40.7 & 5.48 & 19.0 & 1.47 & 2.7 & 4.11 & 194 & & 2.13 & & -14.3 & -108 & $<10$ \\
\hline HTH-2 & 229 & 29-Jul-92 & 19.5 & $7.84 / 8.10$ & $303 / 300$ & 29.2 & 40.8 & 5.52 & 19.0 & 1.47 & 2.6 & 4.08 & $177 / 196$ & & 2.22 & 0.08 & -14.2 & -107 & \\
\hline HTH-2 & 229 & 22-May-93 & & & & & & & & & & & & & & & -14.3 & -106 & \\
\hline HTH-2 & 274 & 22-May-93 & & & & & & & & & & & & & & & -13.9 & -105 & \\
\hline HTH-2 & 297 & 29-Jul-92 & 20.5 & $7.94 / 8.13$ & $299 / 293$ & 29.5 & 40.8 & 5.49 & 18.4 & 1.44 & 2.6 & 4.08 & $161 / 197$ & & 2.22 & 0.06 & -14.2 & -107 & \\
\hline
\end{tabular}

'First number is a measurement in the field at the time of sample collection. Second number is a laboratory measurement. If there is only one number, it is a laboratory measurement. 
Table 1. Chemical and Isotopic Analyses of Groundwater Samples from the Faultless Site. All units are $\mathrm{mg} / \mathrm{l}$ unless noted otherwise (continued).

\begin{tabular}{|c|c|c|c|c|c|c|c|c|c|c|c|c|c|c|c|c|c|c|c|}
\hline Well & $\begin{array}{l}\text { Depth } \\
\text { (m) }\end{array}$ & Date & $\begin{array}{c}\mathrm{T} \\
\left({ }^{\circ} \mathrm{C}\right)\end{array}$ & $\begin{array}{l}\mathrm{pH}^{1} \\
\text { (S.U.) }\end{array}$ & $\begin{array}{c}\mathrm{EC}^{\mathbf{1}} \\
(\mu \mathrm{S} / \mathrm{cm})\end{array}$ & $\mathrm{SiO}_{2}$ & $\mathrm{Ca}$ & $\mathrm{Mg}$ & $\mathrm{Na}$ & $\mathbf{K}$ & $\mathrm{Cl}$ & $\mathrm{SO}_{4}$ & $\mathrm{HCO}_{3}{ }^{\mathrm{I}}$ & $\mathrm{CO}_{3}$ & $\mathrm{NO}_{3}$ & F & $\begin{array}{l}\delta^{18} \mathrm{O} \\
(\% o)\end{array}$ & $\begin{array}{l}\delta \mathrm{D} \\
(\% o)\end{array}$ & $\begin{array}{c}{ }^{3} \mathrm{H} \\
(\mathrm{pCi} / \mathrm{L})\end{array}$ \\
\hline UC-1-P-1S & 91 & 23-May-93 & & 8.27 & 217 & 25.5 & 23.5 & 1.78 & 23.1 & 1.38 & 2.6 & 0.62 & 134 & & 1.33 & & -14.1 & -104 & $<10$ \\
\hline UC-1-P-1S & 229 & 23-May-93 & & 8.16 & 217 & 24.5 & 23.1 & 1.70 & 23.0 & 1.36 & 2.9 & 0.64 & 134 & & 1.37 & & -14.1 & -105 & $<10$ \\
\hline UC-1-P-2SR & 238 & 24-May-93 & & 9.86 & 277 & 6.0 & 1.40 & 0.22 & 59.9 & 1.32 & 7.6 & 16.6 & 58.0 & 38.9 & $<.04$ & & -15.1 & -114 & $8680 \pm 407$ \\
\hline UC-1-P-2SR & 238 & $15-$ Nov-93 & & & & & & & & & & & & & & & & & $6760 \pm 234$ \\
\hline UC-1-P-2SR & 471 & 29-Jul-92 & & & & & & & & & & & & & & & -15.1 & -115 & \\
\hline UC-1-P-2SR & 485 & 29-Jul-92 & & & & & & & & & & & & & & & -15.1 & -115 & \\
\hline UC-1-P-2SR & 485 & 24-May-93 & & 9.86 & 282 & 15.4 & 1.80 & 0.22 & 61.6 & 1.15 & 5.0 & 21.1 & 53.6 & 41.1 & $<.04$ & & -15.1 & -114 & $5210 \pm 329$ \\
\hline UC-1-P-2SR & 485 & 15-Nov-93 & & & & & & & & & & & & & & & & & $4510 \pm 285$ \\
\hline UC-1-P-2SR & 668 & 29-Jul-92 & & & & & & & & & & & & & & & -15.1 & -116 & \\
\hline UC-1-P-2SR & 668 & 24-May-93 & & 9.10 & 343 & 30.6 & 2.69 & $<.1$ & 78.1 & 0.80 & 6.1 & 30.7 & 124 & 19.8 & $<.04$ & & -15.4 & -115 & $220,000 \pm 1840$ \\
\hline UC-1-P-2SR & 668 & 15-Nov-93 & & & & & & & & & & & & & & & & & $6600 \pm 245$ \\
\hline UC-1-P-2SR & 786 & 24-May-93 & & & & & & & & & & & & & & & -13.1 & $-117 /-116$ & \\
\hline
\end{tabular}

1First number is a measurement in the field at the time of sample collection. Second number is a laboratory measurement. If there is only one number, it is a laboratory measurement. 
- $\mathrm{HTH}-1$

$+\mathrm{HTH}-2$

* UC-1-P-2SR

O UC-1-P-1S

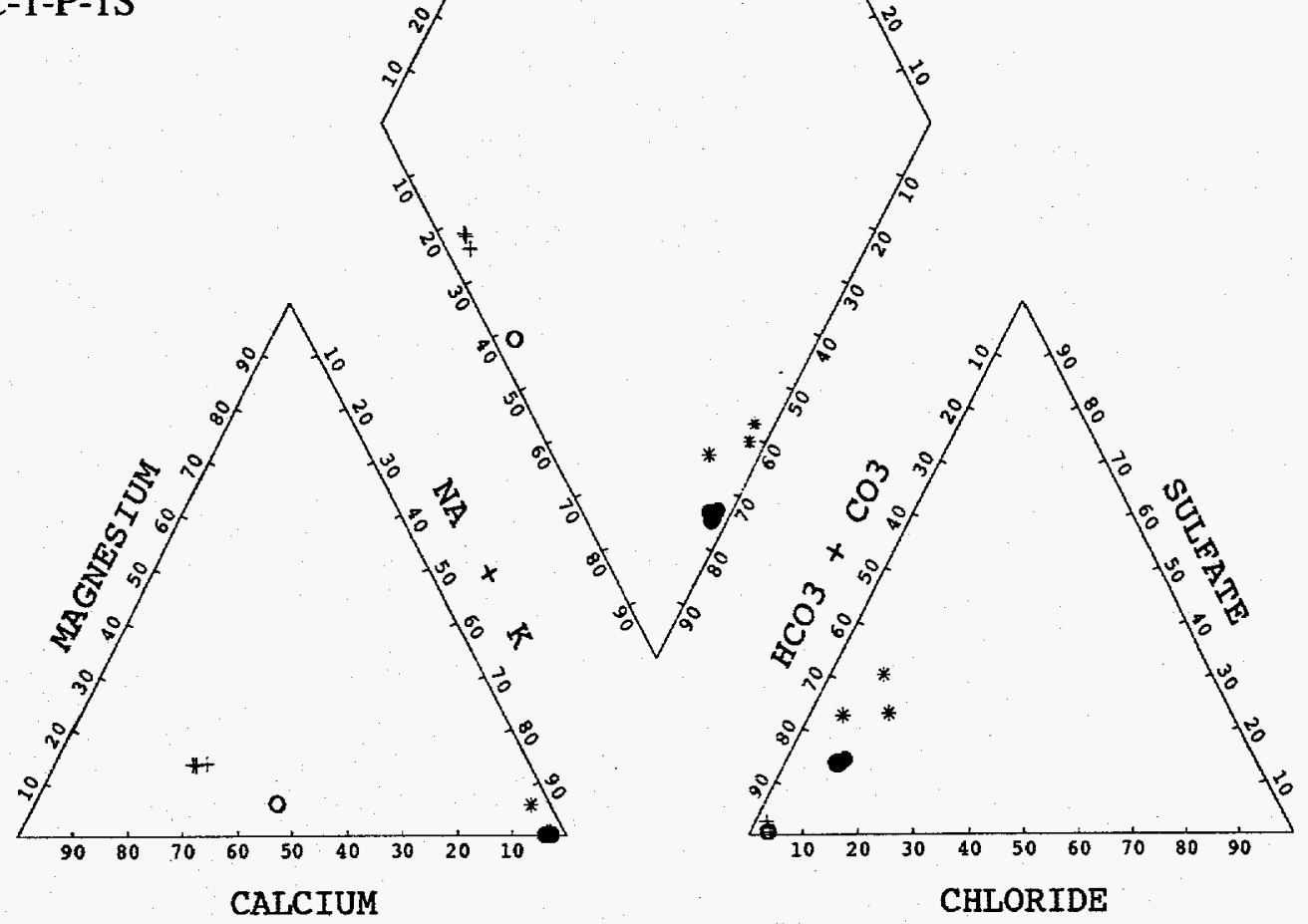

Figure 9. Trilinear diagram of water analyses from the Faultless site. The $\mathrm{Na}-\mathrm{HCO}_{3}$ water found in HTH-1 and UC-1-P-2SR is typical for groundwater in contact with volcanic rocks. It is distinct from the higher calcium water found in HTH-2 and UC-1-P-1S, which may reflect carbonate material in the alluvium.

glacial interval. This is consistent with uncorrected ${ }^{14} \mathrm{C}$ ages of 30,000 to 35,000 years before present for HTH-1 groundwater (Davisson et al., 1994).

The absence of tritium in water moving up from the volcanic aquifers is consistent with the long residence times discussed above. Interpreting the detection of tritium at the upper two screens in July 1992 is complicated by the absence of tritium at these intervals in November 1993. These disparate results either suggest that one set of results is not representative of in situ conditions or that conditions have changed with time. Results from the Long-Term Hydrologic Monitoring Program 


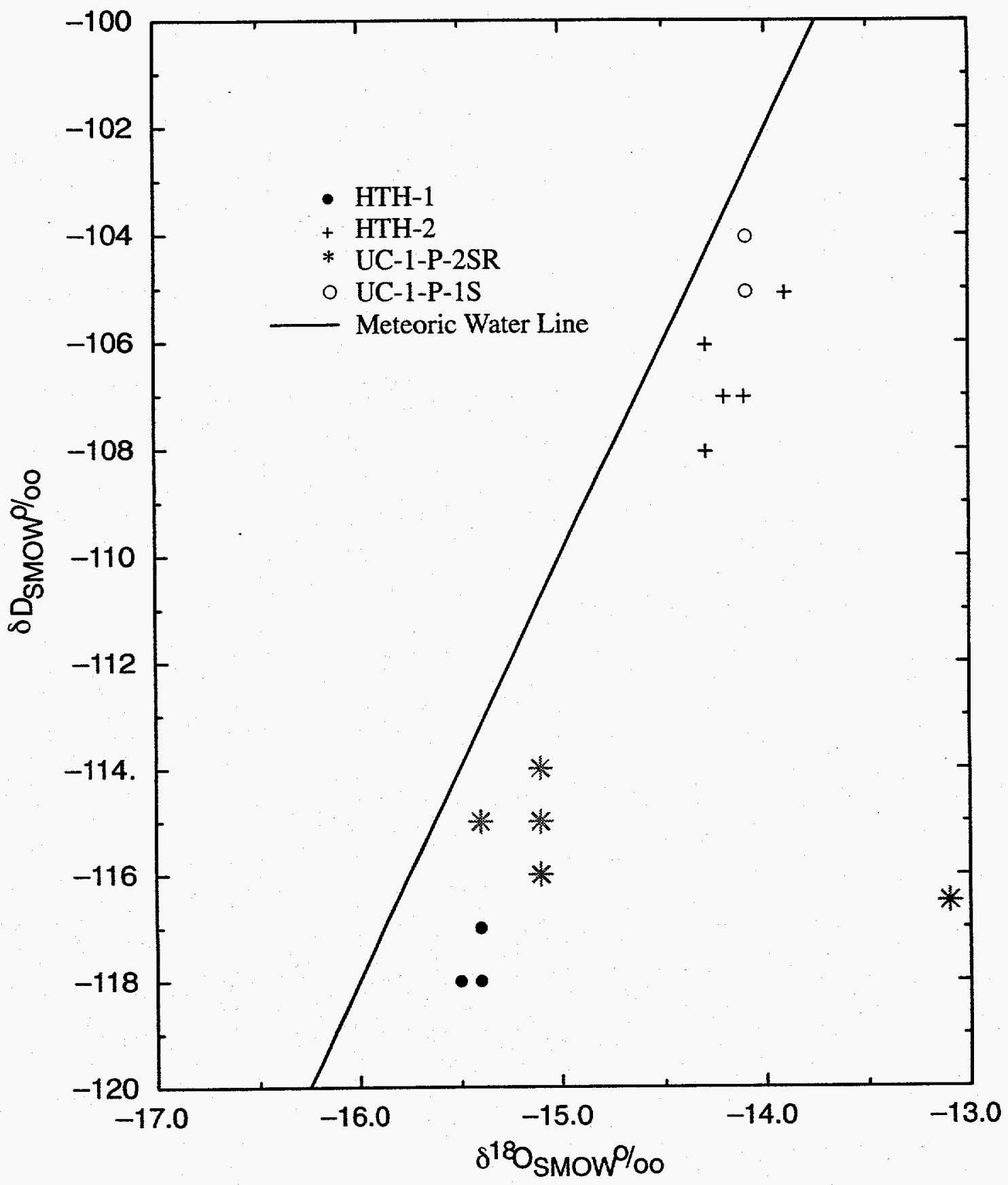

Figure 10. Deuterium and ${ }^{18} \mathrm{O}$ composition of water samples at the Faultless site. Samples from HTH-2 and UC-1-P-1S are enriched in heavy isotopes and probably represent recharge under current climate conditions. The depleted composition of water from HTH-1 and UC-1-P-2SR reflects either recharge at high elevations or recharge under a cooler climate in the past. An ${ }^{18} \mathrm{O}$ shift occurs in the deepest sample from UC-1-P-2SR (768 m) and may reflect isotopic exchange between water and minerals enhanced by the high temperatures generated by the Faultless test. 
(LTHMP) operated for DOE by the U.S. Environmental Protection Agency (EPA) suggest that the 1992 detection of tritium was incorrect. The LTHMP collects samples annually from wells in the Faultless area and analyzes for radioactivity. One sample is collected from HTH-1, at a depth between the two uppermost screens. No detectable tritium has been reported by EPA from those samples (EPA, in prep.).

Contamination during sampling is considered highly unlikely, but cannot be positively ruled out. A month prior to the Faultless field work, the logging vehicle conducted sampling at the NTS in a hole known to contain radioactively contaminated water. The actual sample tube used was retained by Los Alamos National Laboratory, the sample motor was disassembled and decontaminated by thorough rinsing with distilled water, and the cable was washed while tripping out of the hole and then decontaminated at the Decontamination Facility at the NTS. In addition, given the warm temperatures in southern Nevada in the summer, there was ample opportunity for the equipment to air dry, thereby removing any residual tritium. Despite these precautions, the fact remains that a fraction of a drop of contaminated solution could have caused the relatively low tritium concentrations detected in the samples, and the two samples in which tritium was detected were the first collected during the July 1992 trip.

If both the 1992 and 1993 results are accurate, then the July 1992 samples must have caught the tail of a plume of tritium moving through the well. As discussed in a later section, there is an apparent hydraulic barrier between the chimney area and HTH-1 that should prohibit migration through the alluvial units, so the likely scenario is a pulse of tritium-contaminated water moving through the volcanic aquifer and intercepted by HTH-1. Some portion of this pulse is then transported up the well to discharge to the upper saturated alluvium. By the time of the 1992 sampling, the pulse would have already passed the well, evidenced by the lack of detectable tritium at the level of the volcanic aquifer screens, and was being flushed out of the well by the steady upward flow discharging through the top screens (evidenced by the tritium concentration being higher at the top screen than the next one down). Presumably, this flushing was complete by the time of the 1993 sampling, 16 months later. The timing of the passage of such a pulse is further constrained by the EPA samples, which detected no tritium in February 1992. Mechanisms leading to the release of a transient pulse are unknown, but repeated logging at both HTH-1 and UC-1P-2SR indicates changing hydraulic conditions with time that could play a role.

Comparison of the November 1993 temperature log to the May temperature log indicates that the flow regime has changed somewhat over the six-month time period. The larger, cooler, temperature perturbation at $735 \mathrm{~m}$ on the November temperature log suggests greater inflow from the welded tuff unit in November. The temperature crossover at $704 \mathrm{~m}$ and increased temperature above that point in the November log suggest that total fluid flow up the borehole to the outflow zones has also increased. At $302 \mathrm{~m}$, another crossover occurs but the temperatures from the two logs remain relatively close. This occurs over the interval of screen 9 and the bottom portion of screen 10. At $250 \mathrm{~m}$, the temperatures from the two logs have about a 0.2 degree separation that is consistent for the remainder of the borehole. This interval is the unperforated portion of the borehole and the upper portion of the tenth perforated zone, which the temperature log indicates is not a conductive 
zone. The merging of temperature profiles between 330 and $250 \mathrm{~m}$ suggests more outflow from screen 9, and possibly screen 8 below it, in November as compared to May. The cooler November temperatures in the vicinity of screen 10 indicate slower upward flow at the top of the well, consistent with more outflow of volcanic water deeper in the well.

\section{HTH-2}

HTH-2 is a hydrologic test hole that was drilled to $304.8 \mathrm{~m}$ and completed with $0.24-\mathrm{m}$ casing that is slotted from $153.6 \mathrm{~m}$ to the bottom of the hole. The casing was hung in a $0.31-\mathrm{m}$-diameter borehole which allows circulation of fluids between the casing and the annulus. It was drilled as an observation well for an aquifer test conducted in $\mathrm{HTH}-1$.

The well construction did not allow the use of the TFM because even with a packer set in this well, fluid could flow between the annulus and the casing, as well as through the TFM. The results from the chemical logging are presented in Figure 11. The specific conductance plot shows a sharp increase of $45 \mu \mathrm{S} / \mathrm{cm}$ in the first $12.5 \mathrm{~m}$ of the well. The remainder of the log indicates little change in specific conductance. The $\mathrm{pH}$ log shows a similar response near the top of the water column, with the remainder of the log showing a gradual rise in $\mathrm{pH}$. The temperature $\log$ is fairly complex considering the simple well completion at HTH-2. The upper $3 \mathrm{~m}$ of the log show a sharp decrease in temperature, which is believed to be the result of the Chem-tool warming the water in the upper portion of the borehole while the tool was allowed to temperature equilibrate with the borehole fluid. The next $14.3 \mathrm{~m}$ are very similar to what was observed at HTH-1. The next $65.8 \mathrm{~m}$ are characterized by a very small geothermal gradient of $0.007^{\circ} \mathrm{C} / \mathrm{m}$ with the remainder of the borehole showing a larger thermal gradient of $0.056^{\circ} \mathrm{C} / \mathrm{m}$.

Water samples were collected from HTH-2 on July 29 and August 6, 1992, and May 22, 1993. Samples were collected near the bottom of the hole, at a depth consistent with the top screen in HTH-1, and near the top of the water column. The samples are all very similar in chemical composition, describing a Ca- $\mathrm{HCO}_{3}$ water of low salinity (Table 1 and Figure 9). The stable isotopic composition varies from a $\delta^{18} \mathrm{O}$ of -13.9 to $-14.3 \%$ and a $\delta \mathrm{D}$ of -105 to $-108 \%$. No tritium was detected in the two samples analyzed.

\section{Interpretation of HTH-2 Data}

The temperature log indicates that water is entering the borehole near the top where the temperature gradient decreases ( $186 \mathrm{~m}$ below surface, Figure 11). It flows downward with a large portion of it exiting near the break in slope where the higher thermal gradient is observed (at about $260 \mathrm{~m}$ ). A smaller quantity of water continues to move downward where it is lost to the formation through a widespread zone, evidenced by the temperature gradient in the lower section being below the assumed geothermal gradient.

The water chemistry in HTH-2 is quite distinct from that in HTH-1, despite both being open to similar sections of alluvium. This is further evidence that all the groundwater in HTH- 1 is derived from the lower volcanics and no longer represents water in the alluvium. The lower salinity, higher 

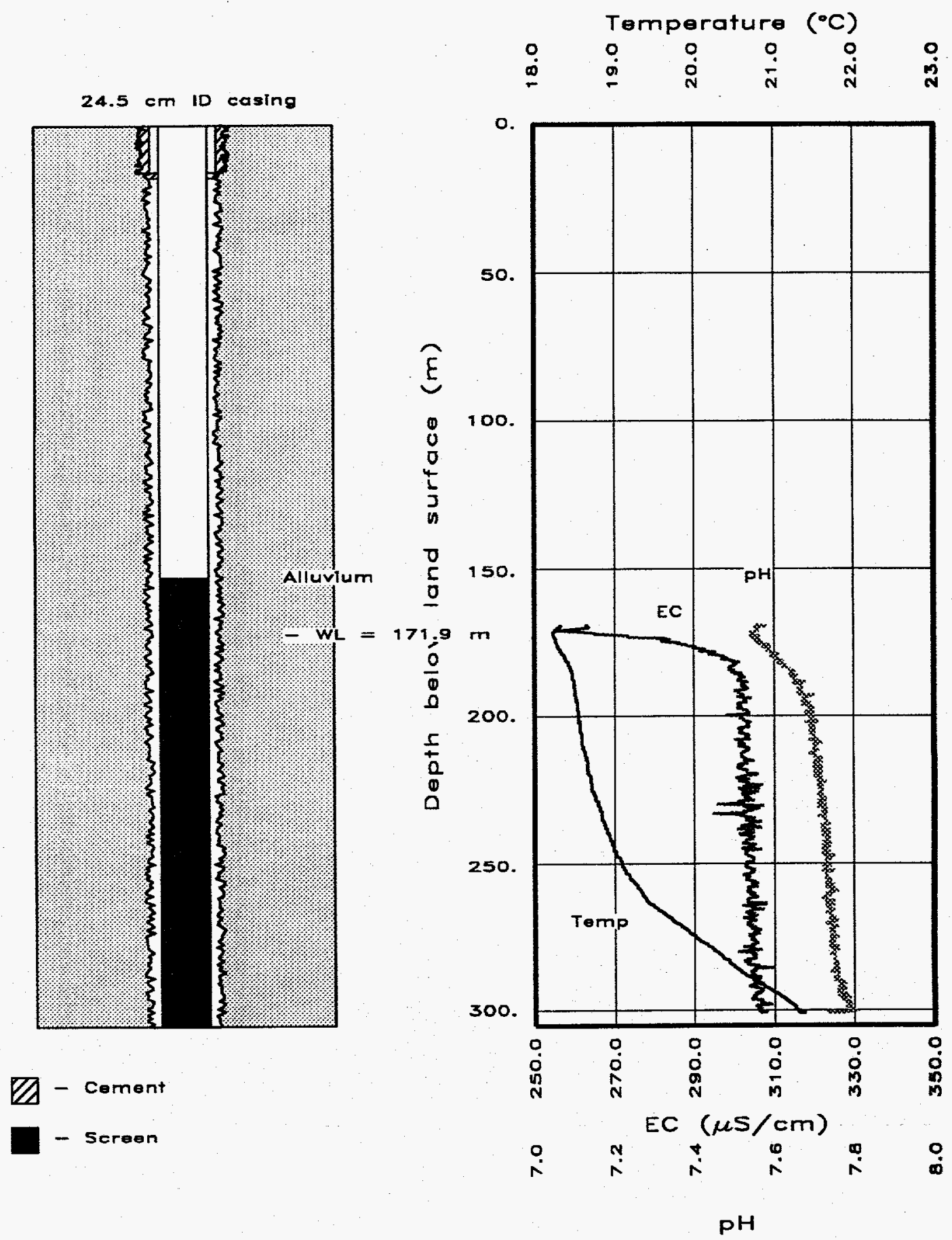

Figure 11. Borehole completion and hydro-chemical logs (run May 1993) from HTH-2. Strong downward flow is suggested by all of the logs between depths of 186 and $260 \mathrm{~m}$, with a smaller quantity of flow continuing down to the bottom of the well and possibly past the logged depth (drilled depth is at least $4 \mathrm{~m}$ lower than the logging tool could access). 
calcium, magnesium, and nitrate concentrations, and enriched isotopic composition (Figure 10) all point to HTH-2 being a much younger, less chemically evolved water than that from HTH-1. This is supported by the very young ${ }^{14} \mathrm{C}$ ages obtained by Lawrence Livermore National Laboratory on samples collected by DRI in July 1992 and May 1993. The uncorrected age is approximately 2000 years before present (Davisson et al., 1994) and indicates that the area around the Faultless event is an active recharge area. Despite efforts to isolate it, the lower salinity zone at the top of the hole, defined by the chemical log, was not captured during sampling.

\section{UC-1-P-1S}

UC-1-P-1S was the first postshot hole drilled for the Faultless event. Caving and artesian conditions were encountered at a depth of $325 \mathrm{~m}$. The 0.25 -m-diameter hole was drilled to a depth of $833.28 \mathrm{~m}$ when the drill rig became stuck. The drill pipe was cut off at $293.8 \mathrm{~m}$ and the hole was completed with $0.11-\mathrm{m}$ casing that is slotted between 10.42 and $281.14 \mathrm{~m}$. The type of well completion precludes the use of the TFM, and because of the small casing diameter, the chemical logging tool could not be used. The hole was logged with a borehole logging tool that measures only temperature and specific conductance. The log from this well is presented in Figure 12 and it should be noted that although this well was slant-drilled toward the cavity, no deviation survey data are available to correct measured depth to true depth. The specific conductance log suggests little variation throughout the borehole. The temperature log shows a very small gradient of $0.003^{\circ} \mathrm{C} / \mathrm{m}$ in the upper $115 \mathrm{~m}$ of the $\log$. At a depth of $200 \mathrm{~m}$, the temperature sharply increases by almost $2^{\circ} \mathrm{C}$ then gradually increases at a gradient of $0.022^{\circ} \mathrm{C} / \mathrm{m}$.

Two water samples were collected from UC-1-P-1S at depths of 91 and $229 \mathrm{~m}$ on May 23, 1993. These samples are a low salinity, $\mathrm{Ca}-\mathrm{HCO}_{3}$ water (Table 1 and Figure 9). The stable isotopic composition (Figure 10) is similar to that in HTH-2, being more enriched in heavy isotopes than HTH-1 or UC-1-P-2SR. Tritium analyses revealed no tritium above $10 \mathrm{pCi} / \mathrm{L}$.

\section{Interpretation of UC-1-P-1S Data}

The logging tool used in this well has not been cross-calibrated with the Chem-tool, making precise comparisons with the geothermal gradient determined with the Chem-tool impossible. The nearly constant water temperature of the first $117 \mathrm{~m}$ of the temperature log indicates strong flow within this part of the well. The large increase in temperature at $200 \mathrm{~m}$ suggests that relatively cool water is flowing down the well from the top, exiting from the well at $200 \mathrm{~m}$. The presence of a thermal gradient below $200 \mathrm{~m}$ suggests either no flow or slowly moving water in the bottom part of the borehole, but the noise in the data makes the log difficult to interpret in that zone. The rough similarity between the bottom hole temperature and the proposed thermal gradient (Figure 6) indicates there is not significant upward flow from the blocked section of the borehole.

Although the conductivity log shows some variation in the well, the water samples collected at 91.4 and $228.6 \mathrm{~m}$ have essentially the same chemical composition. Chemically, UC-1-P-1S more closely resembles the alluvium water sampled in $\mathrm{HTH}-2$ than the volcanic water from $\mathrm{HTH}-1$. The anion percentages are virtually identical for $\mathrm{HTH}-2$ and UC-1-P-1S, though in terms of cations, 


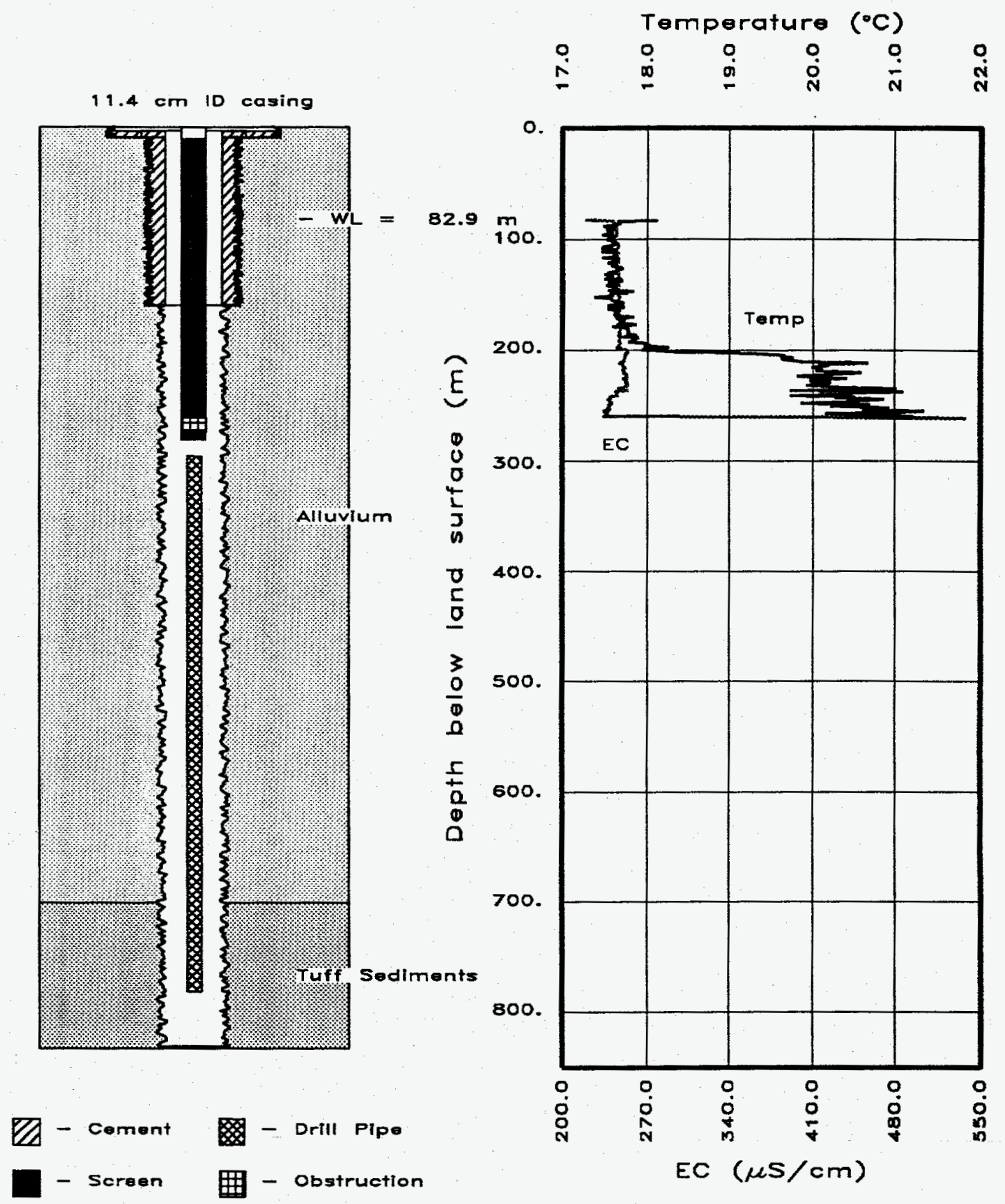

Figure 12. Borehole completion and hydro-chemical logs (run May 1993) from UC-1-P-1S. Data shown represent depth in slanted hole. The measured depths could be significantly different than the vertical depth below land surface. The temperature log indicates strong downward flow in the top portion of the well, exiting into a zone near a depth of $200 \mathrm{~m}$. Little or no flow apparently occurs in the bottom logged portion of the well. 
UC-1-P-1S has less calcium. The cation difference could be related to the large loss of mud in the postshot hole during drilling, but the overall salinity is actually less than HTH-2. The stable isotopic composition is similar for UC-1-P-1S and HTH-2, indicating that UC-1-P-1S also contains recently recharged water, as proposed for HTH-2. The source of the lower salinity water at UC-1-P-1S cannot be drilling fluid contamination because water used for drilling at Faultless came from a deep well completed in volcanics (UCe-18) that had a much higher salinity than found in any of the Faultless samples (Dinwiddie and Schroder, 1971). Brikowski (1993) suggests that UC-1-P-1S may be in more direct communication with the recharge area than HTH-2 and that low permeability along faults related to the test may be causing a mound of recharge to form in the UC-1-P-1S area.

\section{UC-1-P-2SR}

The postshot hole, UC-1-P-2SR, was drilled to a depth of $822.9 \mathrm{~m}$, then three sidetrack holes were drilled from that point. Land surface elevation at the hole is $1855 \mathrm{~m}$ and it should be noted that the depths reported here have not been corrected for the angled nature of the borehole, and thus differ from actual depth below land surface. The sidetrack that was cased, known as 2SR, was drilled to a depth of $1097.2 \mathrm{~m}$. There was complete loss of circulation of drilling fluids below a depth of 603 $\mathrm{m}$ and thousands of liters of drilling mud were lost to the formations penetrated by the borehole. Although the well completion is complex, the pertinent features are: 1) the 0.24-m-diameter casing extends from 0 to $595.0 \mathrm{~m}$ and is cemented from 335.26 to $595.0 \mathrm{~m}, 2$ ) the 0.14 -m-diameter casing was hung in the $0.24-\mathrm{m}$ casing from 0 to $857.36 \mathrm{~m}$, and 3) the $0.14-\mathrm{m}$ casing, the $0.24-\mathrm{m}$ casing, and the cement were gun-perforated from 349.89 to $850.35 \mathrm{~m}$. Because lost drilling mud was not cleaned from the hole, Dinwiddie and West (1970) believe that most of the perforations in the 0.14-m casing were probably plugged with mud and natural clay from the surrounding sediments.

In May 1993, the Chem-tool was run from $228.8 \mathrm{~m}$ to an obstruction within the tubing at 797 $\mathrm{m}$ (Figure 13). The specific conductance log exhibits little variation from the water surface to a depth of $595 \mathrm{~m}$. At $595 \mathrm{~m}$, a sharp increase of $30 \mu \mathrm{S}$ occurred followed by a gradual increase for the remainder of the well at a rate of $0.038 \mu \mathrm{S} / \mathrm{m}$. The $\mathrm{pH}$ in the upper portion of the well through the entire cemented section is consistently above 9.8 . The $\mathrm{pH}$ sharply decreased by $0.4 \mathrm{pH}$ units below the cemented portion of the well. The $\mathrm{pH}$ continued to decrease, however, the rate of decrease varied in the lower portion of the well, possibly indicative of zones of inflow or outflow. In the upper isolated portion of the well, the temperature increased at $0.033^{\circ} \mathrm{C} / \mathrm{m}$, essentially at the hypothesized geothermal gradient. In the perforated cemented portion of the well beginning at approximately 350 $\mathrm{m}$, the temperature sharply increased from $22.4^{\circ} \mathrm{C}$ to $26.3^{\circ} \mathrm{C}$, then gradually increased for the following $222 \mathrm{~m}$ at $0.001^{\circ} \mathrm{C} / \mathrm{m}$. At the bottom of the cemented portion of the well (at $595 \mathrm{~m}$ ), the temperature sharply increases again from $27.8^{\circ} \mathrm{C}$ to $31^{\circ} \mathrm{C}$, then increases at approximately the geothermal gradient to below $700 \mathrm{~m}$. A line drawn from the temperature trend around $300 \mathrm{~m}$ to the trend line at $650 \mathrm{~m}$ is the presumed geothermal gradient, if no flow existed. Below $700 \mathrm{~m}$, the temperature increases at an exponential rate to $54.4^{\circ} \mathrm{C}$ at $796.9 \mathrm{~m}$, which is the bottom of the accessible well.

In November of 1993, UC-1-P-2SR was relogged with the Chem-tool. At the time of the logging, the $\mathrm{pH}$ sensor was inoperative due to faulty batteries; however, the temperature and specific 


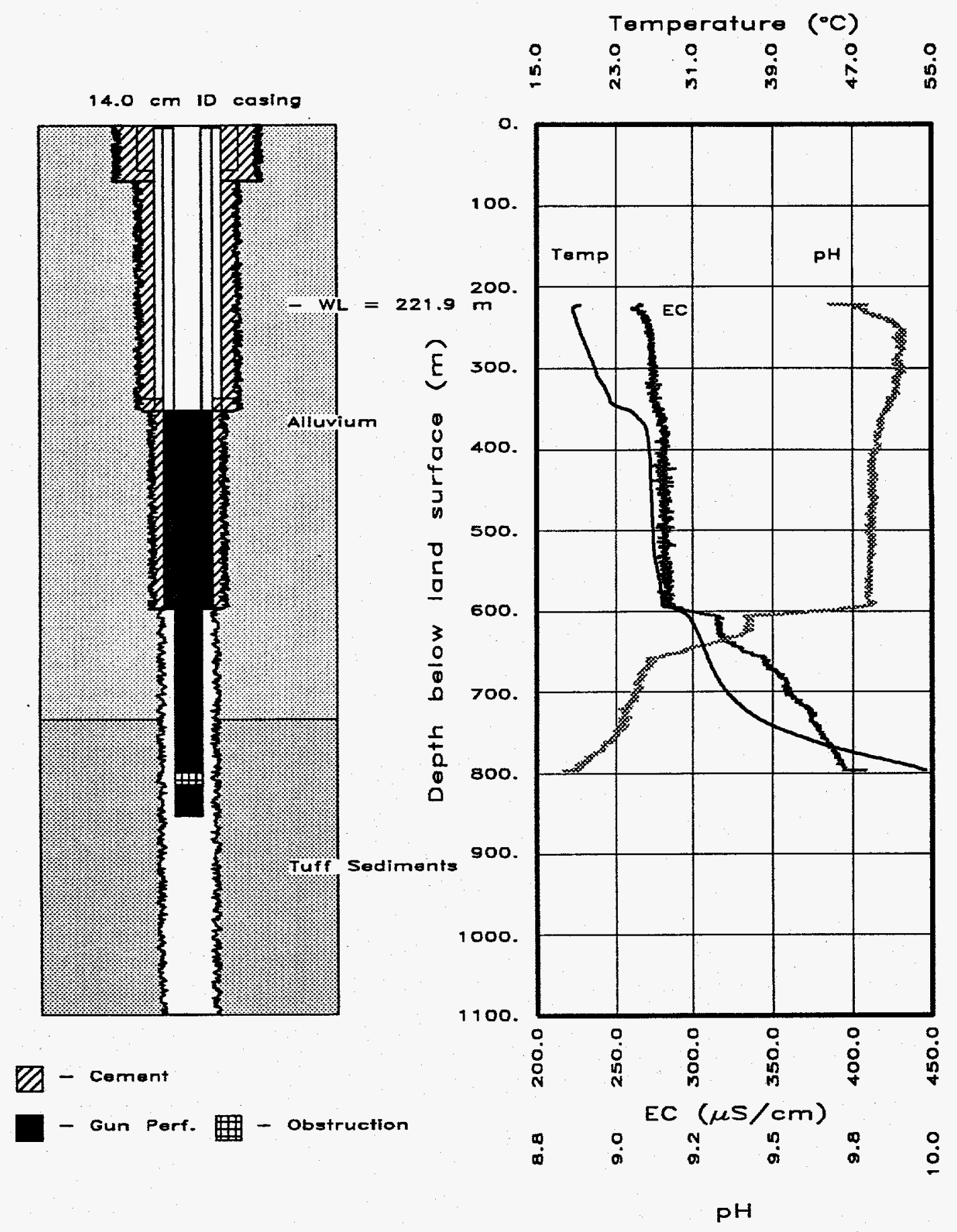

Figure 13. Borehole completion and hydro-chemical log (run in May 1993) from UC-1-P-2SR. Data shown represent depth in slanted hole. The measured depths could be significantly different than the vertical depth below land surface. All parameters indicate a major shift at the change in casing size around $600 \mathrm{~m}$. The $250-\mathrm{m}$ section of relatively constant temperature above $600 \mathrm{~m}$ suggests strong vertical flow in the well. 
conductivity sensors were unaffected by the problem. The temperature and specific conductance logs are shown in Figure 14. Although the chemical logs from Figures 13 and 14 look similar, a close examination of the temperature logs indicate that conditions in the borehole have changed between the May log and the November $\log$ (Figure 15). Just below the water surface the observed difference between the two logs was caused by the tool warming the water in the spring when the logging tool was warm and conversely cooling the water in the fall when the tool was cold. Below this point, the temperature from the two logs are similar, then deviate at $302 \mathrm{~m}$, with the November log being warmer by $0.15^{\circ} \mathrm{C}$. The November log remains slightly warmer to a depth of $348.5 \mathrm{~m}$ where it becomes cooler than the May log and remains cooler to a depth of $595 \mathrm{~m}$. From $595 \mathrm{~m}$ to the bottom of the accessible borehole the temperature logs overlay each other.

Significant temperature deviations are observed in two portions of the borehole. The first deviation occurs between $348.5 \mathrm{~m}$ to $515 \mathrm{~m}$. At $348.5 \mathrm{~m}$, which is the top of the gun perforated zone, the temperature from the November log warms more slowly than the May log. The maximum temperature difference in this interval is $1^{\circ} \mathrm{C}$ at a given depth. At $515 \mathrm{~m}$, the temperatures from the two logs are nearly the same (within $0.04^{\circ} \mathrm{C}$ ). The observed temperature gradient between $385 \mathrm{~m}$ and $515 \mathrm{~m}$. from the May $\log$ is $0.004^{\circ} \mathrm{C} / \mathrm{m}$ and in November it was $0.008^{\circ} \mathrm{C} / \mathrm{m}$. The second significant deviation occurs between 515 and $595 \mathrm{~m}$. In this portion of the borehole, the November $\log$ shows cooler temperatures than the May log. The maximum temperature difference in this portion of the borehole is $0.6^{\circ} \mathrm{C}$. In the November log, a temperature gradient of $0.005^{\circ} \mathrm{C} / \mathrm{m}$ was observed between 515 and $590 \mathrm{~m}$. The May log shows two gradients through this area, first a larger gradient of $0.015^{\circ} \mathrm{C} / \mathrm{m}$ followed by a smaller gradient of $0.007^{\circ} \mathrm{C} / \mathrm{m}$.

UC-1-P-2SR was also logged with the TFM in November. A packer was fabricated to use this tool in the 0.14-m casing; however, because the 0.14-m casing is hung in the 0.24-m casing, the measured flow rates are considered to be minimums. It is probable that additional fluid is moving between the two casing strings. The TFM measurements indicate upward flow from just above 488 $\mathrm{m}$ to near $350 \mathrm{~m}$ and downward flow from $488 \mathrm{~m}$ to $617 \mathrm{~m}$ (Figure 14). No flow was observed below $617 \mathrm{~m}$. The largest upward flow measured was $7.91 / \mathrm{min}$ at $480 \mathrm{~m}$, and the greatest downward flow was $-6.9 \mathrm{l} / \mathrm{min}$ at $518 \mathrm{~m}$.

Water samples for chemical and tritium analysis were collected on May 24, 1993. On July 29, 1993, additional samples were collected for stable isotopic analysis and on November 15, 1993, additional tritium samples were collected for comparison to May tritium samples. Only samples from the upper part of the well $(238,485$, and $668 \mathrm{~m}$ below land surface) were chemically analyzed due to the high levels of tritium in the lower sample. The samples were all $\mathrm{Na}-\mathrm{HCO}_{3}$ waters (Table 1 and Figure 9). Salinity increased with depth, as did sodium, calcium, sulfate, and bicarbonate concentrations. The stable isotopes cluster at $\delta^{18} \mathrm{O}$ of $-15.1 \%$ and $\delta \mathrm{D}$ of -115 to $-116 \%$, except for a sample collected at $768 \mathrm{~m}$, which has a composition of $\delta^{18} \mathrm{O}=-13.1 \%$ and $\delta \mathrm{D}=-116$ to $-117 \%$. All of the samples had measurable tritium (Table 1), though the values did not follow a logical progression of increasing with depth. The shallowest May sample (from $238 \mathrm{~m}$ ) had $8680 \mathrm{pCi} /$, while the sample from $485 \mathrm{~m}$ had $5210 \mathrm{pCi} / 1$ and the one from $668 \mathrm{~m}$ had $220,000 \mathrm{pCi} / 1$. The 

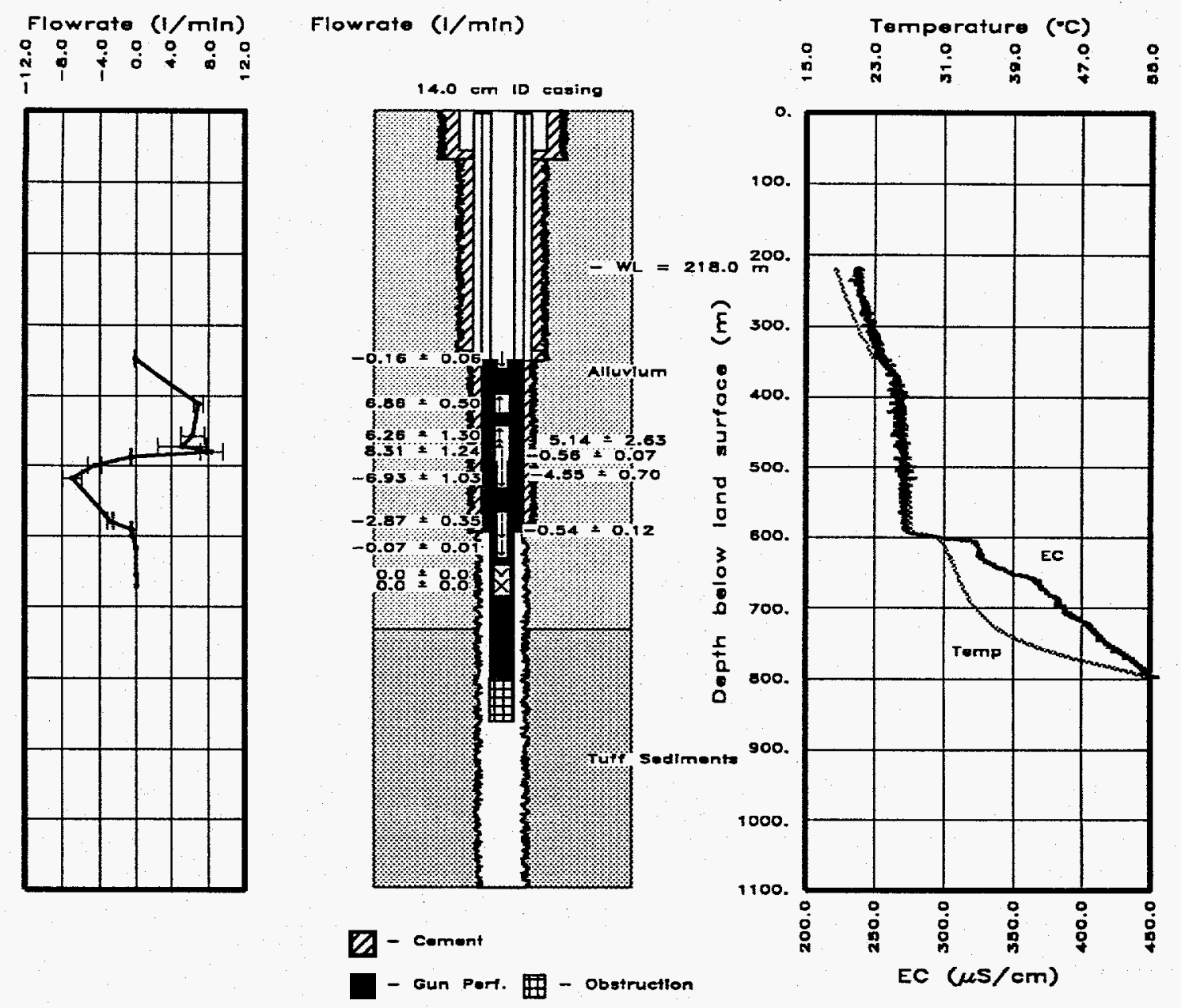

Figure 14. Chemical and thermal flow logs from UC-1-P-2SR, run in November 1993. Data shown represent depth in slanted hole. The measured depths could be significantly different from the vertical depth below land surface. Differences between this temperature log and the one run in May 1993 can be seen on Figure 15 . The flow log indicates water entering the borehole around $488 \mathrm{~m}$ and moving both up and down to exit around $350 \mathrm{~m}$ and $591 \mathrm{~m}$. 


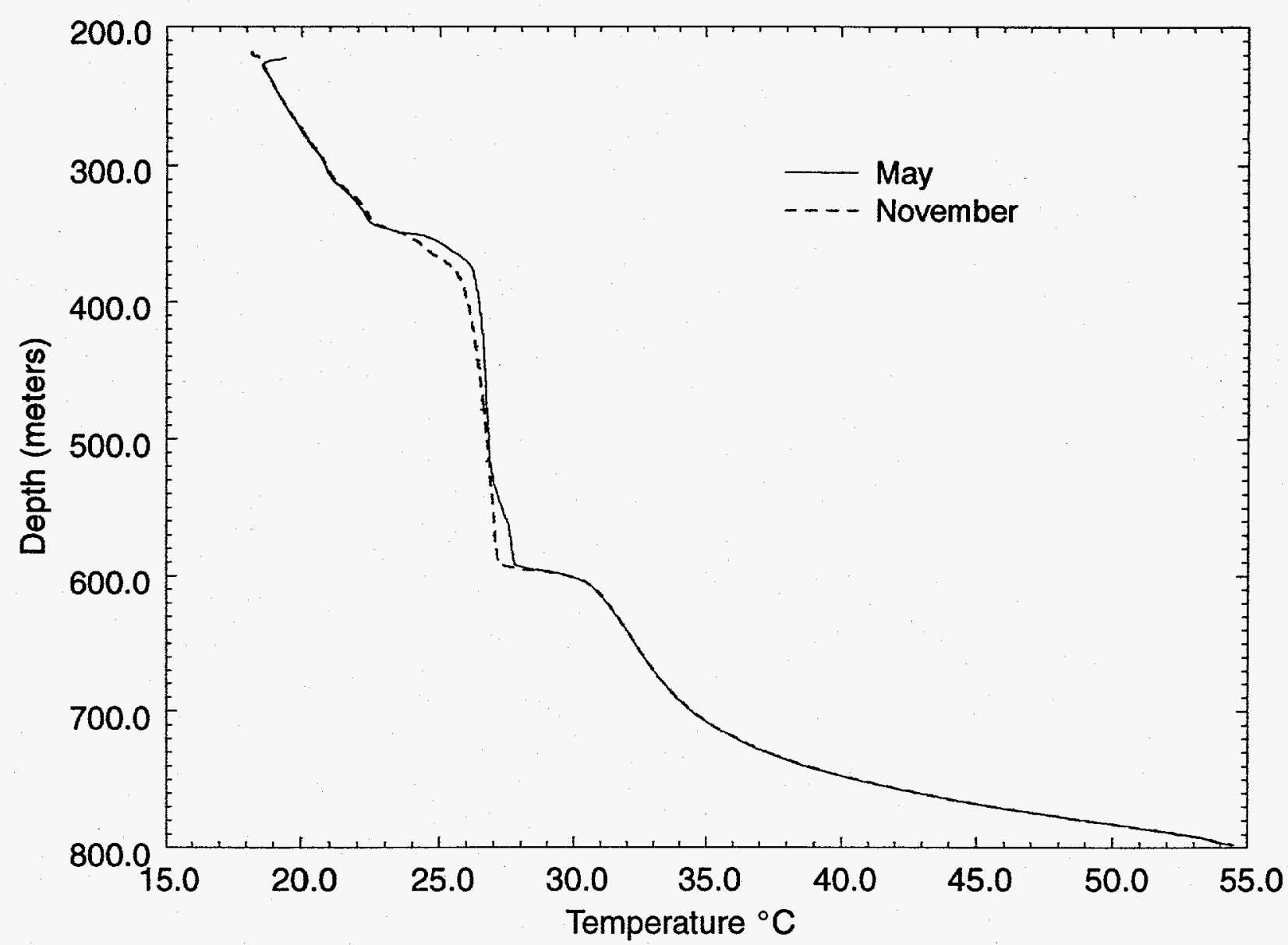

Figure 15. Comparison of May 1993 and November 1993 temperature logs from UC-1-P-2SR.

November samples were collected at the same depths $(238,485$, and $668 \mathrm{~m})$ and had 6760,4510 , and $6600 \mathrm{pCi} / 1$, respectively.

\section{Interpretation of UC-1-P-2SR Data}

The thermal flow and temperature logs indicate that water enters UC-1-P-2SR between 480 and $487 \mathrm{~m}$, approximately the depth at which the geothermal gradient intersects the temperature log (Figure 6). Water flows both up and down the borehole from this entry point, indicated by flowmeter measurements and the very small temperature gradient. The downward flow persists to at least 590 $\mathrm{m}$ at a maximum rate of $2.2 \mathrm{1} / \mathrm{min}$. Below $617 \mathrm{~m}$ there is very little vertical movement in the borehole indicating that water must exit the casing near the transition from the cemented, perforated casing to the perforated casing hung in the borehole with no cement. The upward flow is at a higher, though variable rate (up to $7.9 \mathrm{l} / \mathrm{min}$ ) and persists to about $350 \mathrm{~m}$. The majority of the upward flow apparently exits the borehole at approximately $380 \mathrm{~m}$. Above $350 \mathrm{~m}$, in the unperforated portion of the casing, there is an indication of slight downward flow, possibly due to fluid movement through 
damaged casing. The inflow zone and both the upper and lower outflow zones are in the alluvium section and within the chimney defined by Thordarson (1985) as created by the nuclear test. The water entering the well is warmer by several degrees Celsius than expected for groundwater in the alluvium at that depth.

Comparison of the two temperature logs indicates the flow regime in the borehole has changed between May and November. Near the inflow zone at $480 \mathrm{~m}$, the two logs are comparable, however above that point the November log is cooler, which would indicate that upward flow in the casing was less in November as compared to May. Moving downward from the inflow zone, the November log again is cooler than the May log indicating that downward flow in the casing increased in November.

The $\mathrm{pH}$ and conductivity logs (Figure 13) respond in a similar but inverse manner to each other throughout the borehole. The straight-line response from these logs in the upper portion of the borehole supports the vertical water movement seen in the temperature logs and the thermal flow $\log$. The changes through the lower section of the borehole are difficult to interpret since the response of these logs may be the result of rapid chemical weathering created by higher temperature water at the bottom of the borehole.

Chemically, the water sampled from UC-1-P-2SR is similar to the volcanic water sampled in HTH-1, though all of the UC-1-P-2SR samples were collected in the alluvium section. The high pH values measured in the upper samples are believed to reflect interaction with cement. Though the ion ratios suggest interaction with volcanics, the salinity of the postshot samples is much less than that of water from HTH-1, implying a shorter residence time or dilution by mixing with fresher water. Indeed, the upper samples are slightly less saline than alluvial water from HTH-2, posing the same problem as at UC-1-P-1S in terms of source of fresh water and raising the possibility of enhanced infiltration of recharge throughout the fault block. There is a chemical change between the upper samples and the one collected at $668 \mathrm{~m}$ (the deeper sample having higher TDS, more $\mathrm{Ca}$, $\mathrm{Na}, \mathrm{SO}_{4}$, and $\mathrm{HCO}_{3}$ than the shallower ones), supporting the interpretation of inflow of water above $668 \mathrm{~m}$. Isotopically, the postshot water more closely resembles the volcanic water from HTH-1 (Figure 10), suggesting a pluvial recharge environment inconsistent with the shorter residence times indicated by the salinity. The enrichment in $\delta^{18} \mathrm{O}$ in the sample from $786 \mathrm{~m}$ probably reflects water-mineral isotopic exchange prompted by the geothermal conditions induced by the nuclear detonation.

The tritium concentration sampled at $485 \mathrm{~m}$ should be representative of tritium concentrations in the chimney at that level because that is in the zone of water inflow to the well. It is significant that some of the tritium detected in the borehole enters the well at $485 \mathrm{~m}$, rather than simply moving up the hole from the cavity below. This indicates that tritium is present in the chimney well above the actual cavity. The somewhat higher concentrations of tritium at $668 \mathrm{~m}$ as compared to $485 \mathrm{~m}$ are probably the result of diffusional mixing because $668 \mathrm{~m}$ is below the lower outflow zone and tritium concentrations deeper in the borehole are considerably higher $\left(21 \times 10^{6} \mathrm{pCi} / \mathrm{l}\right.$ at $786 \mathrm{~m}$; Davisson et al., 1994). It is more difficult to determine why concentrations at $238 \mathrm{~m}$ are higher than 
those entering at $485 \mathrm{~m}$. Water at $238 \mathrm{~m}$ is above the upper outflow zone and may have a higher concentration of tritium representative of water that moved through the borehole previously. This higher concentration water could have been due to movement induced by conditions in the borehole and chimney, or it could be mixing in the borehole caused by logging and sampling activities. The higher concentrations at all three sample horizons in May as compared to November are believed to be a result of borehole mixing. Prior to the May sample collection, Lawrence Livermore National Laboratory investigators had spent several days collecting water samples from various depths in the borehole (Davisson et al., 1994). Additionally, hydro-physical logging preceded our sampling efforts in May. Those activities may have brought up water that had higher tritium concentrations from deeper in the borehole. The sample collection in November preceded the logging activities and those samples are probably more representative of the borehole tritium distribution.

Whether from the chimney or the lower portion of the borehole, the ultimate source of the tritium is the nuclear cavity below. The tritium concentration at $668 \mathrm{~m}$ in 1993 continues a steep decline from the peak concentration in 1976 (Figure 16a). This decline is at a rate faster than radioactive decay, indicating mixing with lower concentration water, probably from the inflow zone at $485 \mathrm{~m}$. Conversely, concentrations at $485 \mathrm{~m}$ are increasing, from a concentration of $1500 \mathrm{pCi} / 1$ in 1982 to greater than $4500 \mathrm{pCi} / \mathrm{l}$ in our samples (Figure $16 \mathrm{~b}$ ).

\section{DISCUSSION}

\section{Conditions Outside the Collapse Block}

Water levels in both HTH-1 and HTH-2 responded immediately to the nuclear explosion by increasing over $60 \mathrm{~m}$ at HTH-1 and over $30 \mathrm{~m}$ at HTH-2 (Dinwiddie and West, 1970). The greater rise at HTH-1 is probably due to the confined nature of several of the aquifers penetrated by the well. The water level in neither of these wells has returned to pre-event conditions, remaining $6 \mathrm{~m}$ elevated in HTH-1 and 3.7 m elevated in HTH-2 (Figure 17). The logging and sampling results from HTH-1 suggest pre-existing hydrologic conditions may explain the long-term increase in water levels. The flow log indicates water moving upward from the volcanic units, exiting into saturated alluvium at the top two screens in the saturated section. This movement is not at a high velocity, as indicated by the TFM measurements of about $3 \mathrm{l} / \mathrm{min}$ and the direct correlation between depth and temperature showing that the effect of the geothermal gradient is not overwhelmed by the vertical flow. Given the higher head in the volcanic units, one explanation for the sustained elevation of heads at HTH-1 is that the "pre-event" level measured by Dinwiddie (1972) and referred to by him as a composite head is more representative of head in the alluvial aquifer, while the current level is representative of natural conditions in the volcanic aquifers.

The other possibility is that there has been a long-term change in hydraulic conditions caused by the nuclear test. Shortly after well drilling, the individual screened intervals in HTH-1 were isolated and tested, with the highest head measured as $166.7 \mathrm{~m}$ below land surface (compared to $162.2 \mathrm{~m}$ currently). Comparison of the 1993 flowmeter results with a tracejector survey run in 1968 (Dinwiddie and Schroder, 1971) also indicates that hole conditions have changed. The tracejector 

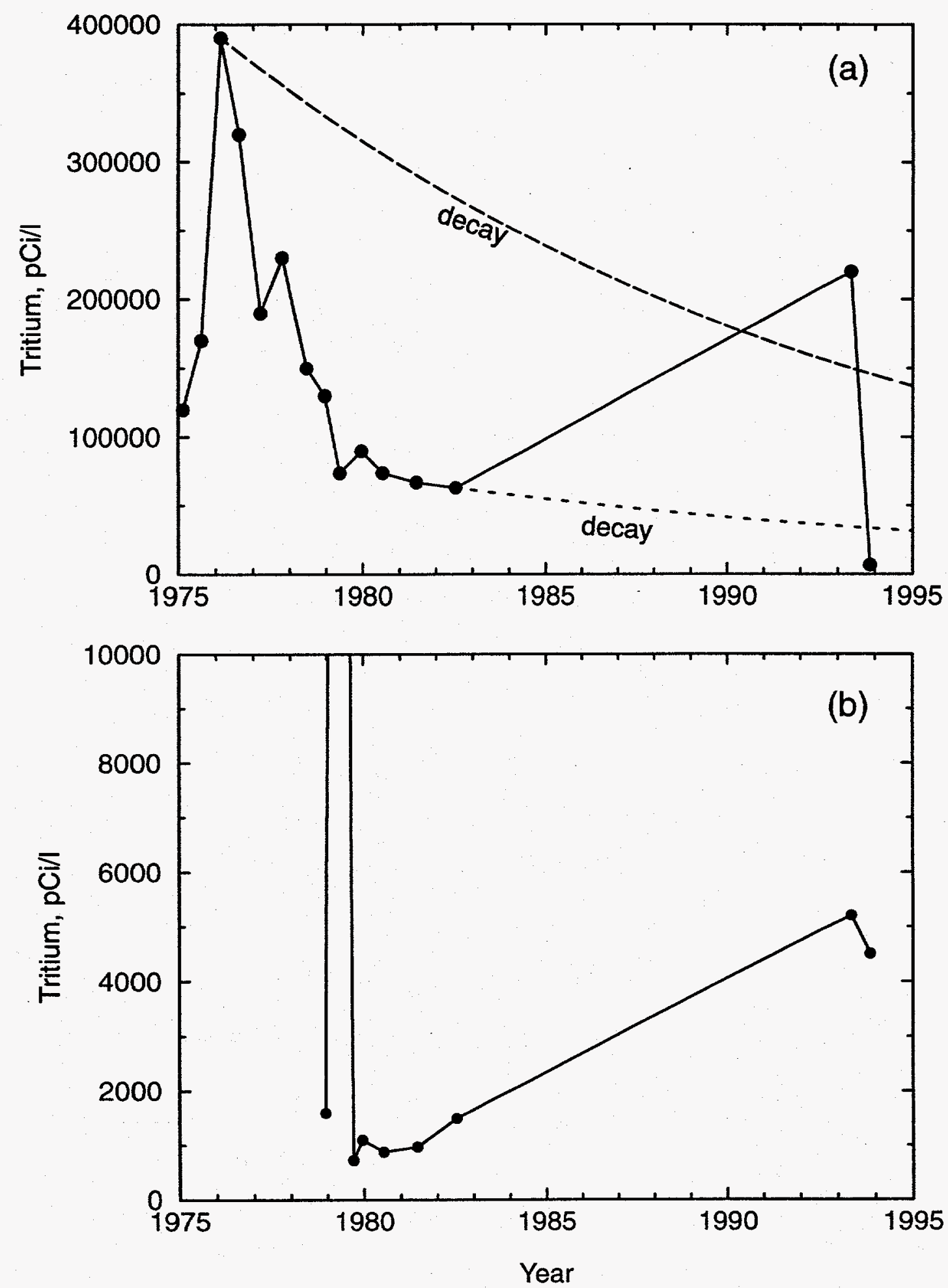

Figure 16. Tritium concentration through time for water samples collected a) at $668 \mathrm{~m}$, and b) between 454 and $466 \mathrm{~m}$ in UC-1-P-2SR. Concentrations at $454 \mathrm{~m}$ are rising, while those at $668 \mathrm{~m}$ are declining at a rate faster than radioactive decay. All data are from Thordarson (1985), with the exception of the data collected for the present study in 1993. The off-scale point in 1979 of $48,000 \mathrm{pCi} / \mathrm{l}$ collected at $454 \mathrm{~m}$ was not confirmed by any other samples and is probably the result of cross-contamination during sampling. 


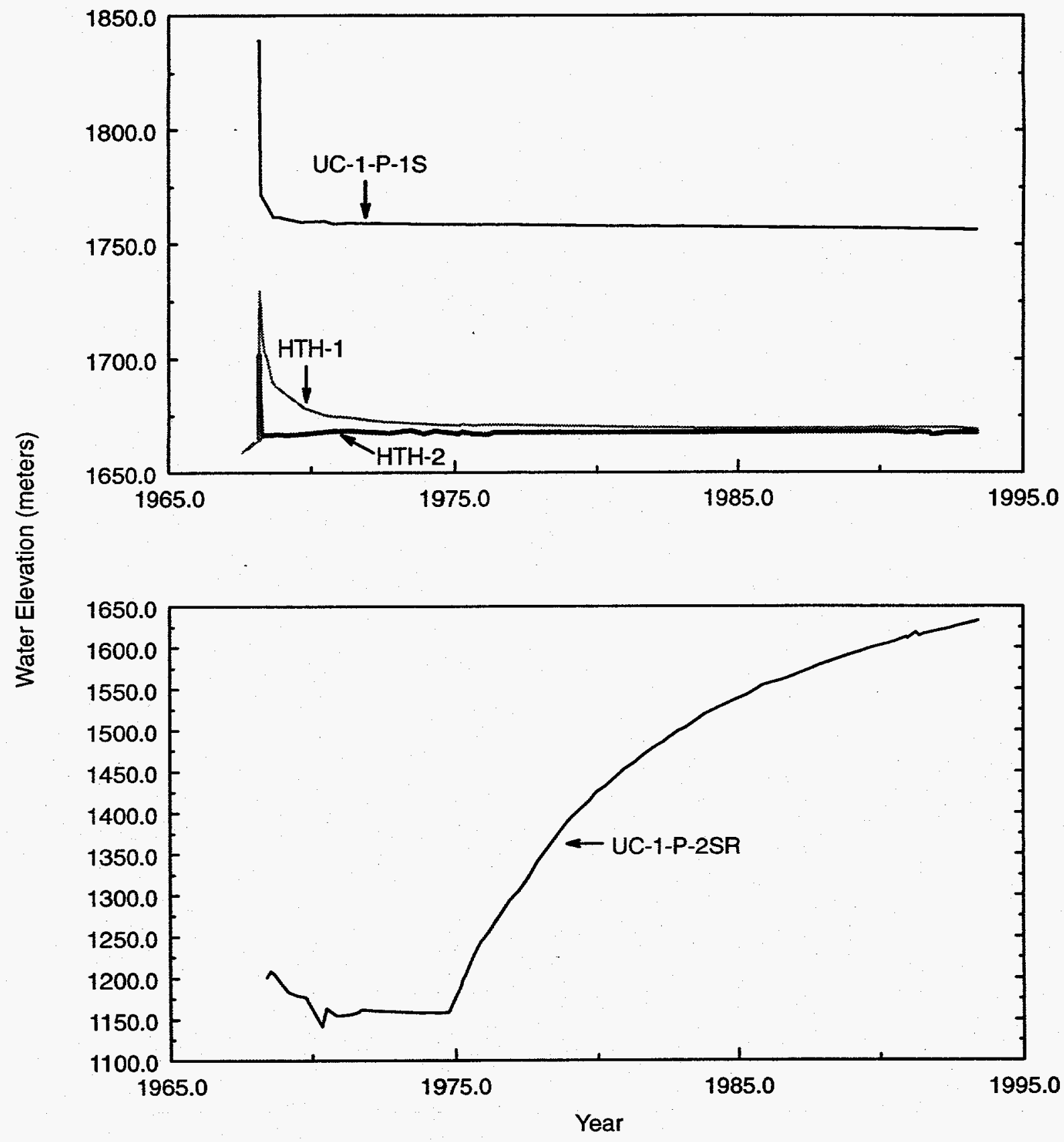

Figure 17. Water elevation history for boreholes at the Faultless site. Both HTH-1 and HTH-2 have remained elevated relative to pre-shot conditions and water levels in UC-1-P-1S (drilled after the shot) are much higher than at the nearby HTH monitoring wells. The water level in UC-1-P-2SR continues to recover toward the preshot water elevation of $1687 \mathrm{~m}$. 
survey found flow from the welded tuff (zone 4) moving both upward and downward at a rate about three times higher than was measured in 1993. Thus there appears to have been a shift to higher pressure below the welded tuff than existed prior to the Faultless event. Differences in borehole flow detected by the May and November 1993 logging events indicate that conditions in the borehole continue to change, though the two datasets are not sufficient to determine if the changes are periodic or part of a long-term trend.

The continued elevated head at HTH-2 may indicate a change in pressure in the alluvial aquifer related to Faultless, or could be part of a mound in the water table caused by the discharge of volcanic water in the alluvium at HTH-1. HTH-2 is $154 \mathrm{~m}$ from HTH-1 and though the pressure front may have migrated that distance, the water chemistry clearly indicates that the water discharging from HTH-1 is not present at HTH-2.

The consequences of the two basic scenarios explaining the elevated heads at HTH-1 and HTH-2 (shot induced or a borehole imposed on natural pressure conditions) are very different in terms of detecting contaminant transport. If the elevated heads at HTH-1 and HTH-2 are merely the result of the well completion in HTH-1, the mound of water around these wells would deflect contaminants away from them. Unless radionuclides migrate in one of the higher-pressure volcanic horizons, neither well would be useful for monitoring. If, on the other hand, the elevated head at HTH-2 is part of a widespread hydraulic phenomenon caused by the test, then the wells will monitor water in the alluvium and volcanic units to the extent they are downgradient of the source.

\section{Conditions Inside the Collapse Block}

The water level in UC-1-P-1S is much higher than in any of the other wells. Following a rapid drop from its originally artesian condition (when drilled immediately after the nuclear test), the water level has remained relatively constant, with the current level of $83 \mathrm{~m}$ below land surface only slightly lower than the previous measurement of $80 \mathrm{~m}$ in 1971. This contrasts with UC-1-P-2SR (referred to below as simply 2SR), which has a lower water level than all the other holes, but has been rising at a steady rate (Figure 17). The depressed water level at 2SR is the result of thermal and compressional forces generated by the Faultless event, with the subsequent water level increase due to infilling of the cavity and chimney from surrounding saturated rocks. At the present infill rate, it is projected that the Faultless water level will reach the pre-event level in another 10 to 15 years (between the years 2004 to 2009). The depression in the water table caused by the nuclear test would usually suggest that contaminants could not migrate from the chimney until pre-event water levels are reached. The logging results from $2 S R$, however, suggest that outflow from the well is occurring at a depth between 340 and $372 \mathrm{~m}$, with additional outflow between 590 and $617 \mathrm{~m}$. In addition, groundwater in the chimney contains tritium in a higher pressure zone around $485 \mathrm{~m}$. Though the interaction between water in the chimney and adjacent alluvial units is unknown, there is a possibility of migration of tritiated water away from the chimney under present conditions. The water level in 2SR reached 372 m sometime between 1982 and 1984, so if outflow from the well is related to outflow from the chimney, there is the possibility that transport of contaminants from the Faultless chimney has been occurring for 10 years. 
If the head measurement at UC-1-P-1S (referred to below as simply 1S) is representative of the area, such transport could not go far in the pre-event downgradient direction before being blocked by a ridge of high hydraulic pressure. Brikowski (1993) speculates that the head in $1 \mathrm{~S}$ could be the result of development of low conductivity zones along collapse faults causing groundwater to "back-up." Another fault separates the chimney and 1S (at least on the surface), presumably preventing the excess head at $1 \mathrm{~S}$ from draining into the chimney. If this is the case, the pre-event hydraulic conditions cannot be used to predict contaminant migration pathways and probable migration directions cannot be identified. Many problems were experienced at UC-1-P-1S during drilling and, though not accessible for logging, the hole does slant into the cavity region, so conditions in the well may not represent hydraulic conditions throughout the collapse block. Even if the head is caused by well-specific conditions, the hydraulic mound created at that point serves to perturb the flow field and force groundwater flow laterally around the mound.

The source of water sampled at 2SR has yet to be identified. Unlike water from HTH-1 and HTH-2, the data from 2SR are contradictory, with the low salinity suggesting a water with a short residence time while the light stable isotopes suggest long residence times. The most plausible explanation is an older volcanic water that has been diluted by a very fresh water. The presence of volcanic-type water, tritium, and the elevated temperatures in the alluvium sampled at $2 \mathrm{SR}$ may indicate the existence of a large-scale convection cell moving water and contaminants up through the chimney from the cavity area below. This water may be mixing with recently recharged groundwater that infiltrates along the flanks of Morey Peak.

\section{CONCLUSIONS}

Prior to the chemical logging, thermal flowlogging, and water sampling of this study, contaminant outflow from the Faultless event was not expected until the pre-event water level was reached in another 10 to 15 years, and wells HTH-1 and HTH-2 were believed to be located in a probable downgradient direction to monitor for migration. This study has revealed that neither of these assumptions is necessarily correct. The thermal flow log from the postshot hole shows outflow from the well into a zone of low pressure at a depth of approximately $350 \mathrm{~m}$ below land surface. If this low pressure zone also drains the chimney, migration of contaminants away from the Faultless event could have been occurring for the last 10 years since the chimney filled to that depth by 1984 . Temperature logs and water samples indicate the movement of deeper water upward through the chimney, possibly as part of a convection cell created by the high temperatures near the nuclear cavity. An unidentified source of water is apparently contributing to chimney infilling, perhaps moving into the fault block from the upgradient direction of Morey Peak.

Though hydraulic gradients are not well known in Hot Creek Valley, wells HTH-1 and HTH-2 were located in the probable downgradient direction from the test, based primarily on topography. The flowlogging, chemical logging, and sampling demonstrated conclusively that the two wells sample separate hydraulic units: a volcanic aquifer and the alluvial aquifer. Stratification within each of these major aquifer types is also obvious. Unfortunately, the completion of HTH-1, open throughout its length to higher pressures from the volcanic aquifers, may have created a groundwater 
mound around the two monitoring wells that diverts natural, lateral flow in the alluvium away from them. In this case, only contaminant transport in the volcanic units contributing to HTH-1 could be monitored by the present system. Even if the head conditions at the two wells are part of a widespread hydraulic response to the Faultless event, the presence of the very high water level in UC-1-P-1S may represent another barrier to flow from the cavity toward the monitoring wells. Thus, recent field investigations have determined that there is a possibility for contaminant migration away from the Faultless event though the pre-event water level has not been attained, while new data from the monitoring wells and an abandoned postshot hole raise questions about the ability of the current monitoring network to detect migration.

\section{REFERENCES}

Brikowski, T., 1993, A Computer-Based Conceptual Model of the Hydrology of the Faultless Site. Desert Research Institute, Water Resources Center publication \#45112, U.S. Department of Energy, Nevada Operations Office Report DOE/NV/10845-28, 18.5-min. videotape.

Chapman, J.B. and S.L. Hokett, 1991, Evaluation of Groundwater Monitoring at Offsite Nuclear Test Areas. Desert Research Institute, Water Resources Center Publication \#45085, U.S. Department of Energy, Nevada Operations Office report DOE/NV/10845-07, UC-703, 82p.

Chapman, J.B.,T.M. Mihevc and B.F. Lyles, 1992, Field Investigation at the Faultless Site, Central Nevada Test Area. Desert Research Institute, Water Resources Center letter report to U.S. Department of Energy, Nevada Operations Office, 5p. +appendices.

Craig, H., 1961, Isotopic variations in meteoric waters. Science, V. 133, pp. 1702-1703.

Davisson, M.L., G. Nimz, G. Hudson, D. Smith, J. Rego and J. Kenneally, 1994, FY-92 Report on the Isotope Hydrology Characterization of the Faultless Test Site, Nye County, Nevada. Lawrence Livermore National Laboratory Report, UCRL-ID-116133, 17p.

Dinwiddie, G.A. and S.W. West, 1970, Hydrologic Phenomena at the Faultless Site, Hot Creek Valley, Nevada. U.S. Geological Survey unnumbered report, 24p.

Dinwiddie, G.A., 1972, Summary of Recent Hydrologic Data, Faultless Site, Hot Creek Valley, Nevada. U.S. Geological Survey unnumbered report, 22p.

Dinwiddie, G.A. and L.J. Schroder, 1971, Summary of Hydraulic Testing in and Chemical Analyses of Water Samples From Deep Exploratory Holes in Little Fish Lake, Monitor, Hot Creek, and Little Smoky Valleys, Nevada. U.S. Geological Survey, USGS-474-90, Central Nevada-40, 69p.

Fiero Jr., G.W., J.R. Illian, G.A. Dinwiddie and L.J. Schroder, 1974, Use of Hydrochemistry for Interpreting Ground-Water Flow Systems in Central Nevada. U.S. Geological Survey and Desert Research Institute, USGS-474-178, 44p.

Hoover, D.L., 1968, Lithologic Logs of Drill Holes in the Faultless Area, Hot Creek Valley, Nevada. U.S. Geological Survey Technical Letter: Central Nevada-17, 12p. 
Keys, W.S. and L.M. MacCary, 1971, Application of Borehole Geophysics to Water-Resources Investigations. U.S. Geological Survey, Techniques of Water-Resources Investigations, Book 2, Chapter E1, 126p.

Lyles, B.F., in press, Increased Thermal-Pulse Flowmeter Resolution by Adding a Packer and Computer. Ground Water Monitoring and Remediation.

Rush, F.E. and D.E. Everett, 1966. Water-Resources Appraisal of Little Fish Lake, Hot Creek, and Little Smoky Valleys, Nevada. State of Nevada Department of Conservation and Natural Resources, Water Resources-Reconnaissance Series, Report 38, 38p.

Thordarson, W., 1985, Hydrogeologic Monitoring at the Faultless Site, Nye County, Nevada. U.S. Geological Survey, Open-File Report 84-580, 37p.

Thordarson, W., 1987, Hydrogeology of the Faultless Site, Nye County, Nevada. U.S. Geological Survey, Water-Resources Investigations Report, 86-4342, 40p.

U.S. Department of Energy, Nevada Operations Office, 1992. Nevada Test Site, Annual Site Environmental Report. Office of Scientific and Technical Information.

U.S. Environmental Protection Agency, in prep. Offsite Environmental Monitoring Report: Radiation Monitoring Around United States Nuclear Test Areas, Calendar Year 1992. Environmental Monitoring Systems Laboratory Report. 


\section{DISTRIBUTION}

\section{U.S. Department of Energy}

Gylan Allen

Test Operations Division

Nevada Operations Office

U.S. Dept. of Energy

P.O. Box 98518

Las Vegas, NV 89193-8518

Kevin Cabble

Environmental Restoration Division

Nevada Operations Office

U.S. Dept. of Energy

P.O. Box 98518

Las Vegas, NV 89193-8518

Doug Duncan

Hydrology Program Manager

Office of Environmental Restoration \& Waste

Management

Nevada Operations Office

U.S. Dept. of Energy

P.O. Box 98518

Las Vegas, NV 89193-8518

Don Elle, Director

Environment Protection Division

Nevada Operations Office

U.S. Dept. of Energy

P.O. Box 98518

Las Vegas, NV 89193-8518

Joseph N. Fiore, Acting Asst. Mgr.

Office of Environmental Restoration \& Waste

Management

Nevada Operations Office

U.S. Dept. of Energy

P.O. Box 98518

Las Vegas, NV 89193-8518

Steve Lawrence

Environmental Restoration Division

Nevada Operations Office

U.S. Dept. of Energy

P.O. Box 98518

Las Vegas, NV 89193-8518
Kevin Leary

Environmental Restoration Division

Nevada Operations Office

U.S. Dept. of Energy

P.O. Box 98518

Las Vegas, NV 89193-8518

John S. Ledbetter

Contracts Division

Nevada Operations Office

U.S. Dept. of Energy

P.O. Box 98518, MS 505

Las Vegas, NV 89193-8518

Steve Leedom

Test Operations Division

Nevada Operations Office

U.S. Dept. of Energy.

P.O. Box 98518

Las Vegas, NV 89193-8518

Steve Mellington, Director

Environmental Restoration Division

Nevada Operations Office

U.S. Dept. of Energy

P.O. Box 98518

Las Vegas, NV 89193-8518

Richard Pearl

Environmental Protection Division

Nevada Operations Office

U.S. Dept. of Energy

P.O. Box 98518

Las Vegas, NV 89193-8518

David S. Shafer

NV/Albuquerque Laboratories Division

Office of Southwestern Area Programs

U.S. Department of Energy

EM-452, Trevion II

Washington, D.C. 20585

Tom Longo

NV/Albuquerque Laboratories Division

Office of Southwestern Area Programs

U.S. Department of Energy

EM-452, Trevion II

Washington, D.C. 20585 
Technical Information Resource Center

Nevada Operations Office

U.S. Dept. of Energy

P.O. Box 98518

Las Vegas, NV 89193-8518

\section{U.S. Department of Defense}

David Bedsun

Defense Nuclear Agency

U.S. Department of Defense

P.O. Box 98539

Las Vegas, NV 89193-8539

\section{U.S. Environmental Protection Agency}

Deb Chaloud

Environmental Monitoring Systems Lab.

Office of Radiation Protection

U.S. Environmental Protection Agency

P.O. Box 93478

Las Vegas, NV 89193

\section{Lawrence Livermore National Laboratory}

Lee Davisson

Nuclear Chemistry Division

Lawrence Livermore National Laboratory

P.O. Box 808, MS L237

Livermore, CA 94550

Greg Nimz

Lawrence Livermore National Laboratory

P.O. Box 808, MS L233

Livermore, CA 94550

\section{Los Alamos National Laboratory}

Joe Thompson

Los Alamos National Laboratory

INC-11, MS J514

P.O. Box 1663

Los Alamos, NM 87545

\section{U.S. Geological Survey}

Virginia Glanzman

U.S. Geological Survey

Box 2506, MS 913

Denver Federal Center

Denver, CO 80225

Randy Laczniak

U.S. Geological Survey

Water Resources Division

6770 S. Paradise Rd.

Las Vegas, NV 89119

Paul Orkild

U.S. Geological Survey

Box 2506, MS 913

Denver Federal Center

Denver, CO 80225

Doug Trudeau

U.S. Geological Survey

Water Resources Division

6770 S. Paradise Rd.

Las Vegas, NV 89119

Desert Research Institute

Roger Jacobson

Desert Research Institute

Water Resources Center

P.O. Box 19040

Las Vegas, NV 89132-0040

Marjory Jones

Desert Research Institute

Water Resources Center

P.O. Box 60220

Reno, NV 89506-0220

Paul Seaber

Desert Research Institute

Water Resources Center

P.O. Box 19040

Las Vegas, NV 89132-0040

Dick French

Desert Research Institute

Water Resources Center

P.O. Box 19040

Las Vegas, NV 89132-0040 
Reynolds Electrical \& Engineering Co.

Martha DeMarre

Chief, Document Research Section

Health Protection Dept.

Reynolds Electrical \& Engineering Co.

P.O. Box 98521

Las Vegas, NV 89193-8521

\section{Brian Dozier}

Reynolds Electrical \& Engineering Co.

2501 Wyandotte

Mercury, NV 89102

\section{State of Nevada}

Larry Franks

Nevada State Health Department

Radiological Health Section

620 Belrose Avenue

Las Vegas, NV 89158

\section{LIBRARIES}

Archives

Getchell Library

University of Nevada, Reno

Beverly Carter

MacKay School of Mines Library

University of Nevada, Reno

Stead Library

Desert Research Institute

Reno, Nevada

Southern Nevada Science Center

Water Resources Center, Library

P.O. Box 19040

Las Vegas, NV 89132-0040
Document Section, Library

University of Nevada, Las Vegas

4505 Maryland Parkway

Las Vegas, NV 89154

Annie Kelley

State Documents Department

Nevada State Library

Capitol Complex

Carson City, NV 89710

Water Resources Research Archives

University of California

Room 40, North Gate Hall

Berkeley, CA 94720

International Technology Corp.

Rick Waddell

Geotrans

clo IT

4330 Valley View

Suite 112

MS-439

Las Vegas, NV 89103

Joe Yeasted

International Technology Corp.

4330 Valley View

Suite 112

MS-439

Las Vegas, NV 89103

John Eberlin

International Technology Corp.

4330 Valley View

Suite 112

MS-439

Las Vegas, NV 89103 